\title{
Diversity of Seahorse Species (Hippocampus spp.) in the International Aquarium Trade
}

\author{
Sasha Koning ${ }^{1}$ and Bert W. Hoeksema ${ }^{1,2, *(D)}$ \\ 1 Groningen Institute for Evolutionary Life Sciences, University of Groningen, P.O. Box 11103, \\ 9700 Groningen, The Netherlands; sas.koning@hotmail.com \\ 2 Taxonomy, Systematics and Geodiversity Group, Naturalis Biodiversity Center, P.O. Box 9517, \\ 2300 Leiden, The Netherlands \\ * Correspondence: bert.hoeksema@naturalis.nl
}

Citation: Koning, S.; Hoeksema, B.W Diversity of Seahorse Species (Hippocampus spp.) in the International Aquarium Trade. Diversity 2021, 13, 187. https:/ / doi.org/10.3390/d13050187

Academic Editor: Michael Wink

Received: 16 February 2021

Accepted: 23 April 2021

Published: 29 April 2021

Publisher's Note: MDPI stays neutra with regard to jurisdictional claims in published maps and institutional affiliations.

Copyright: (c) 2021 by the authors. Licensee MDPI, Basel, Switzerland. This article is an open access article distributed under the terms and conditions of the Creative Commons Attribution (CC BY) license (https:/ / creativecommons.org/licenses/by/ $4.0 /)$.

\begin{abstract}
Seahorses (Hippocampus spp.) are threatened as a result of habitat degradation and overfishing. They have commercial value as traditional medicine, curio objects, and pets in the aquarium industry. There are 48 valid species, 27 of which are represented in the international aquarium trade. Most species in the aquarium industry are relatively large and were described early in the history of seahorse taxonomy. In 2002, seahorses became the first marine fishes for which the international trade became regulated by CITES (Convention for the International Trade in Endangered Species of Wild Fauna and Flora), with implementation in 2004. Since then, aquaculture has been developed to improve the sustainability of the seahorse trade. This review provides analyses of the roles of wild-caught and cultured individuals in the international aquarium trade of various Hippocampus species for the period 1997-2018. For all species, trade numbers declined after 2011. The proportion of cultured seahorses in the aquarium trade increased rapidly after their listing in CITES, although the industry is still struggling to produce large numbers of young in a cost-effective way, and its economic viability is technically challenging in terms of diet and disease. Whether seahorse aquaculture can benefit wild populations will largely depend on its capacity to provide an alternative livelihood for subsistence fishers in the source countries. For most species, CITES trade records of live animals in the aquarium industry started a few years earlier than those of dead bodies in the traditional medicine trade, despite the latter being 15 times higher in number. The use of DNA analysis in the species identification of seahorses has predominantly been applied to animals in the traditional medicine market, but not to the aquarium trade. Genetic tools have already been used in the description of new species and will also help to discover new species and in various other kinds of applications.
\end{abstract}

Keywords: aquaculture; CITES Trade Database; cryptobenthic fishes; FishBase; identification; pygmy seahorses; species discovery; World Register of Marine Species (WoRMS)

\section{Introduction \\ 1.1. International Trade in Marine Ornamental Fishes}

Apart from their role in the global food industry, marine fisheries are also engaged in the collection and export of tropical ornamental marine fishes for the international aquarium trade, which is a growing industry involving thousands of species and millions of individuals per year [1-7]. Most marine aquarium fish are still taken from the wild, in particular from coral reefs and surrounding environments, providing low-income coastal communities with a livelihood but also causing the aquarium industry to attract controversy in terms of sustainability [8-10]. This trade is connected with severe ecological risks, such as overharvesting of some species and destructive collecting methods [8,11-15] and the introduction of non-native species in the importing countries [9,16-20]. Collecting ornamental fish with the help of nets [21-23] can cause a pollution problem when the 
nets are lost and animals are strangled in them [24]. Other concerns are raised around the high mortality rate due to bad conditions during transport and the lack of proper husbandry facilities along the supply chain $[10,25,26]$. Shallow-water marine habitats are already under pressure due to the results of climate change, unsustainable fishing, land reclamation, and pollution. It is therefore vital that the collection of marine fish for aquaria does not cause further damage [27]. One group of marine animals popular in the global ornamental fish trade and vulnerable to population decline are the seahorses (Hippocampus spp.). The charisma of seahorses makes them iconic flagship species to address challenges and solutions in marine conservation [28].

\subsection{International Trade in Seahorses (Hippocampus spp.)}

Seahorse species (Syngnathidae: Hippocampus) are also among the fishes that are subject to overfishing and other anthropogenic disturbances, such as habitat loss [29]. Millions of seahorses are collected each year globally to meet the demand of the traditional Chinese medicine market and the marine ornamental industry [28,30-34], which are mostly caught by nonselective fishing methods and partly as bycatch [35-40] but also by hand [41]. Hippocampus species range in maximum body length from about $1.5 \mathrm{~cm}$ in length to $35 \mathrm{~cm}$ (Table 1) and are characterized by their fused jaws, prehensile tail, bony plated skeleton, and typical upright posture [42,43]. Owing to their characteristic appearance and suitable size, seahorses are popular among sea aquarium hobbyists. Seahorses have a unique reproduction style in which the female deposits eggs in an abdominal chamber of the male, where the young are incubated [43]. Seahorses are live bearers, which means that after the eggs are fertilized and brooded, the male gives birth by releasing tens to hundreds of juveniles into the water [44].

At present, there are 48 accepted Hippocampus species (Table 1). They occur in tropical and subtemperate shallow waters all over the world but mostly in the IndoPacific $[30,45,46]$. The combined pressure from habitat degradation as a result of anthropogenic and natural disturbances, and illegal and unregulated fishing of seahorses, has raised concerns over the overexploitation of some species [28,47]. This led to the inclusion of all Hippocampus species (as the first marine fishes) into Appendix II of CITES (Convention for the International Trade in Endangered Species of Wild Fauna and Flora) since 2002 with implementation in 2004 [33,48-50]. This means that all CITES Parties need to ensure that international trade does not harm wild populations; CITES does not directly address threats that are not related to international trade [51-53]. A party to CITES is a state or regional economic integration organization for which the Convention has entered into force. At present, there are 183 Parties [54]. Four Parties (Guinea, Senegal, Thailand, and Vietnam) had difficulties following the CITES regulations and became the focus of a CITES Review of Significant Trade, which eventually resulted in trade suspensions for these four countries [49]. These regulations and the concern about overexploitation have stimulated the replacement of the fishing of wild seahorses by commercial aquaculture, thereby possibly reducing the effects on natural populations as suggested earlier $[55,56]$.

\subsection{Captive Breeding}

Cultivation of ornamental organisms entails the spawning, hatching, settling, and growth of juveniles and adults in an enclosed system [57]. Around $90 \%$ of freshwater ornamental fishes are cultured, whereas only $10 \%$ of marine ornamental species are estimated to come from commercial aquaculture [2,58]. The aquaculture of marine aquarium fish is significantly less advanced, and this industry has been slow to develop and is not widely accessible [59-62]. The aquaculture of seahorse species is a relatively new venture, with rising demand and market prices $[43,51,63]$. The commercial culture of seahorses could provide an alternative income for subsistence fishers and accommodate a future rise in global demand [55,64,65]. 
Table 1. Hippocampus species ranked by year of description, with accepted names according to WoRMS [66] and FishBase [67], threat status [68], first year of recorded live or dead specimens (with purpose $\mathrm{T}=$ commercial trade) in CITES Trade Database (included if $>25$ individuals) [69], and maximum recorded length (with references). IUCN Red List categories that apply: NE = Not Evaluated, DD = Data Deficient, LC = Least Concern, VU = Vulnerable, EN = Endangered.

\begin{tabular}{|c|c|c|c|c|}
\hline \multirow{2}{*}{ Name } & \multirow{2}{*}{ IUCN Status } & \multicolumn{2}{|c|}{ First CITES Record } & \multirow{2}{*}{ Maximum Length $(\mathrm{cm})$} \\
\hline & & Live & Dead & \\
\hline H. hippocampus (Linnaeus, 1758) & $\mathrm{DD}$ & 1997 & 2003 & $15.0[30]$ \\
\hline H. erectus Perry, 1810 & VU & 1997 & 2011 & $19.0[30]$ \\
\hline H. trimaculatus Leach, 1814 & $\mathrm{LC}$ & 1997 & 2004 & $22.0[70]$ \\
\hline H. abdominalis Lesson, 1827 & $\mathrm{LC}$ & 1999 & 2007 & $35.0[30]$ \\
\hline H. guttulatus Cuvier, 1829 & $\mathrm{DD}$ & 1997 & & $21.5[71]$ \\
\hline H. comes Cantor, 1849 & VU & 2003 & 2004 & $18.7[30]$ \\
\hline H. coronatus Temminck \& Schlegel, 1850 & DD & 1997 & & $13.3[72]$ \\
\hline H. kuda Bleeker, 1852 & VU & 1997 & 2003 & $17.0[30]$ \\
\hline H. mohnikei Bleeker, 1853 & VU & 1997 & 2003 & $8.0[30]$ \\
\hline H. camelopardalis Bianconi, 1854 & DD & & & $10.0[30]$ \\
\hline H. whitei Bleeker, 1855 & EN & 2002 & & $13.0[30]$ \\
\hline H. algiricus Kaup, 1856 & VU & 2004 & 2004 & $19.0[30]$ \\
\hline H. histrix Kaup, 1856 & VU & 1997 & 2003 & $17.0[30]$ \\
\hline H. lichtensteinii Kaup, 1856 & NE & & & $4.0[30]$ \\
\hline H. ingens Girard, 1858 & VU & 1998 & 2004 & $31.0[30]$ \\
\hline H. breviceps Peters, 1869 & LC & 2002 & & $10.0[30]$ \\
\hline H. angustus Günther, 1870 & $\mathrm{LC}$ & 1999 & & $16.0[30]$ \\
\hline H. tristis Castelnau, 1872 & $\mathrm{NE}$ & & & $18.0[73]$ \\
\hline H. subelongatus Castelnau, 1873 & $\mathrm{DD}$ & 2004 & & $20.0[30]$ \\
\hline H. planifrons Peters, 1877 & $\mathrm{LC}$ & 2011 & & $11.6[74]$ \\
\hline H. zosterae Jordan \& Gilbert, 1882 & $\mathrm{LC}$ & 1998 & & $2.5[30]$ \\
\hline H. capensis Boulenger, 1900 & EN & 2000 & & $12.0[30]$ \\
\hline H. jayakari Boulenger, 1900 & LC & 1998 & & $14.0[30]$ \\
\hline H. kelloggi Jordan \& Snyder, 1901 & VU & 2005 & 2003 & $28.0[30]$ \\
\hline H. sindonis Jordan \& Snyder, 1901 & $\mathrm{LC}$ & & & $10.8[72]$ \\
\hline H. fisheri Jordan \& Evermann, 1903 & $\mathrm{LC}$ & & & $8.0[30]$ \\
\hline H. barbouri Jordan \& Richardson, 1908 & VU & 2002 & 2005 & $15.0[30]$ \\
\hline H. dahli Ogilby, 1908 & LC & & & $14.0[46]$ \\
\hline H. spinosissimus Weber, 1913 & VU & 1998 & 2004 & $17.2[30]$ \\
\hline H. reidi Ginsburg, 1933 & NT & 1997 & 2007 & $17.5[30]$ \\
\hline H. zebra Whitley, 1964 & DD & 2004 & & $9.4[30]$ \\
\hline H. bargibanti Whitley, 1970 & $\mathrm{DD}$ & & & $2.4[30]$ \\
\hline H. minotaur Gomon, 1997 & DD & 2007 & & $5.0[30]$ \\
\hline H. jugumus Kuiter, 2001 & DD & & & $4.4[74]$ \\
\hline H. colemani Kuiter, 2003 & DD & & & $2.7[75]$ \\
\hline H. denise Lourie \& Randall, 2003 & $\mathrm{DD}$ & 2004 & & $2.1[30]$ \\
\hline H. patagonicus Piacentino \& Luzzatto, 2004 & VU & & & $15.0[76]$ \\
\hline H. pusillus Fricke, 2004 & DD & & & $2.8[77]$ \\
\hline H. pontohi Lourie \& Kuiter, 2008 & $\mathrm{LC}$ & & & $1.7[75]$ \\
\hline H. satomiae Lourie \& Kuiter, 2008 & DD & & & $1.4[75]$ \\
\hline H. debelius Gomon \& Kuiter, 2009 & $\mathrm{DD}$ & & & $2.4[78]$ \\
\hline H. tyro Randall \& Lourie, 2009 & DD & & & $6.1[79]$ \\
\hline H. waleananus Gomon \& Kuiter, 2009 & NE & & & $1.8[80]$ \\
\hline H. paradoxus Foster \& Gomon, 2010 & DD & & & $6.5[81]$ \\
\hline H. casscsio Zhang et al., 2016 & DD & & & $13.3[82]$ \\
\hline H. haema Han et al., 2017 & NE & & & $11.4[72]$ \\
\hline H. japapigu Short et al., 2018 & NE & & & $1.6[80]$ \\
\hline H. nalu Short et al., 2020 & NE & & & $2.2[83]$ \\
\hline
\end{tabular}

Although available cultivation techniques already promote acceptable survival rates for some species, there still is a need to improve culture protocols, especially in terms of nutrition and microbiological aspects $[57,84,85]$. Moreover, over the past few decades, there have been many studies on the harmful effects of aquaculture on the environment [86-90]. 
The benefits and risks of aquaculture as well as the potential social and ecological implications need to be assessed before aquaculture can be considered a solution [91].

\subsection{Research Aim}

The aim of this study is to provide insights into the status of international trade in Hippocampus species for the aquarium industry and the extent to which aquaculture can meet the demands in the international trade of marine ornamental fishes. By analyzing available trade data from the CITES Trade Database [69], this review gives an overview of the worldwide seahorse diversity, their use in genetic studies, the current status of seahorse trade with regards to their extinction status according to the IUCN (International Union for Conservation of Nature) Red List of Threatened Species [68,92], maximum lengths of all species, the most traded species (popularity), the difference between numbers of wild-caught and cultured species, the most important import and export countries, and of trends in trade over time. This study also aims to give an overview of current methods of seahorse aquaculture, to highlight potential pitfalls and challenges, and to identify priorities to facilitate a sustainable seahorse trade for future years.

\section{The Natural History of Hippocampus Species}

\subsection{Species Discovery: Nominal and Valid Species}

In order to better understand the presence and absence of Hippocampus species in the international aquarium trade, an overview of the species discovery is presented. Based on data from FishBase and the World Register of Marine Species [66,67], a total of 124 nominal Hippocampus species have been described, 48 (39\%) of which are considered valid (Figure 1; Table 1). Thus, nearly $60 \%$ of the nominal species names are unaccepted synonyms. Most species (both nominal and accepted) were described in the middle of the 19th century (1841-1860) and in the last two decades (2001-2020).
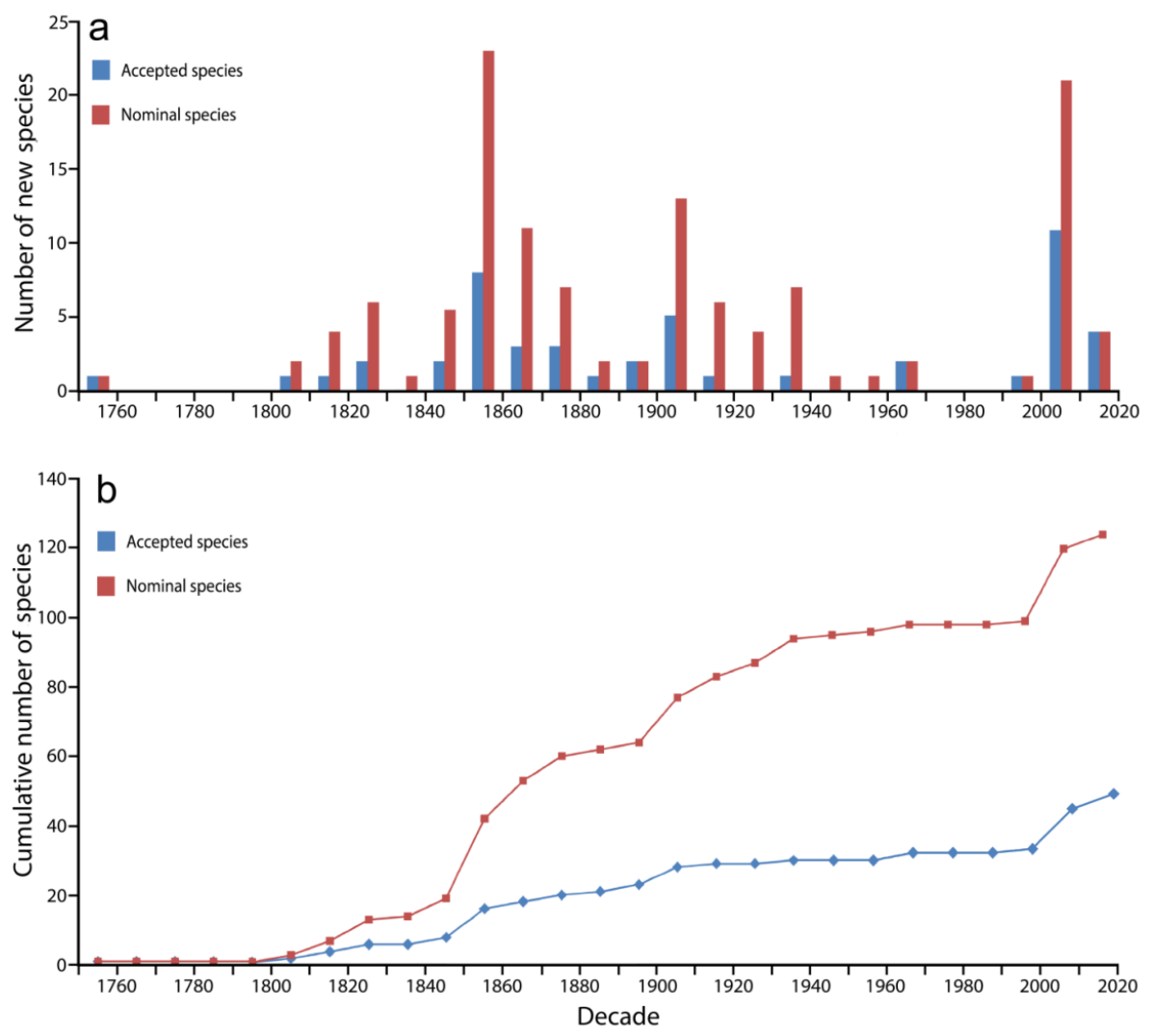

Figure 1. Description of new Hippocampus species, accepted and nominal (1758-2020): numbers per decade (a) and cumulative (b). Original data from FishBase and WoRMS [66,67]. Accepted species are listed in Table 1. 


\subsection{Body Size and Habitat Requirements}

Several recently described species are relatively small and known as pygmy seahorses (Table 1). When body size is plotted against the year of description (Table 1), there appears to be a significant negative relation, indicating that many of the smaller species were discovered later than the larger ones (Figure 2). It is obvious that small species, also known as cryptobenthic fishes, are less conspicuous and therefore more difficult to find and also that they are less well-known than their larger relatives, as also seen in other fish families [93-95]. Some pygmy seahorses are considered host-specific, such as $\mathrm{H}$. denise (Figure 3a) and H. bargibanti, which are usually observed when they are attached to gorgonian octocorals of the genus Annella or other genera [96-107]. Pygmy seahorses use camouflage, mimicking the background of their host, which in addition to their small body size, makes them difficult to detect (Figure 3a).

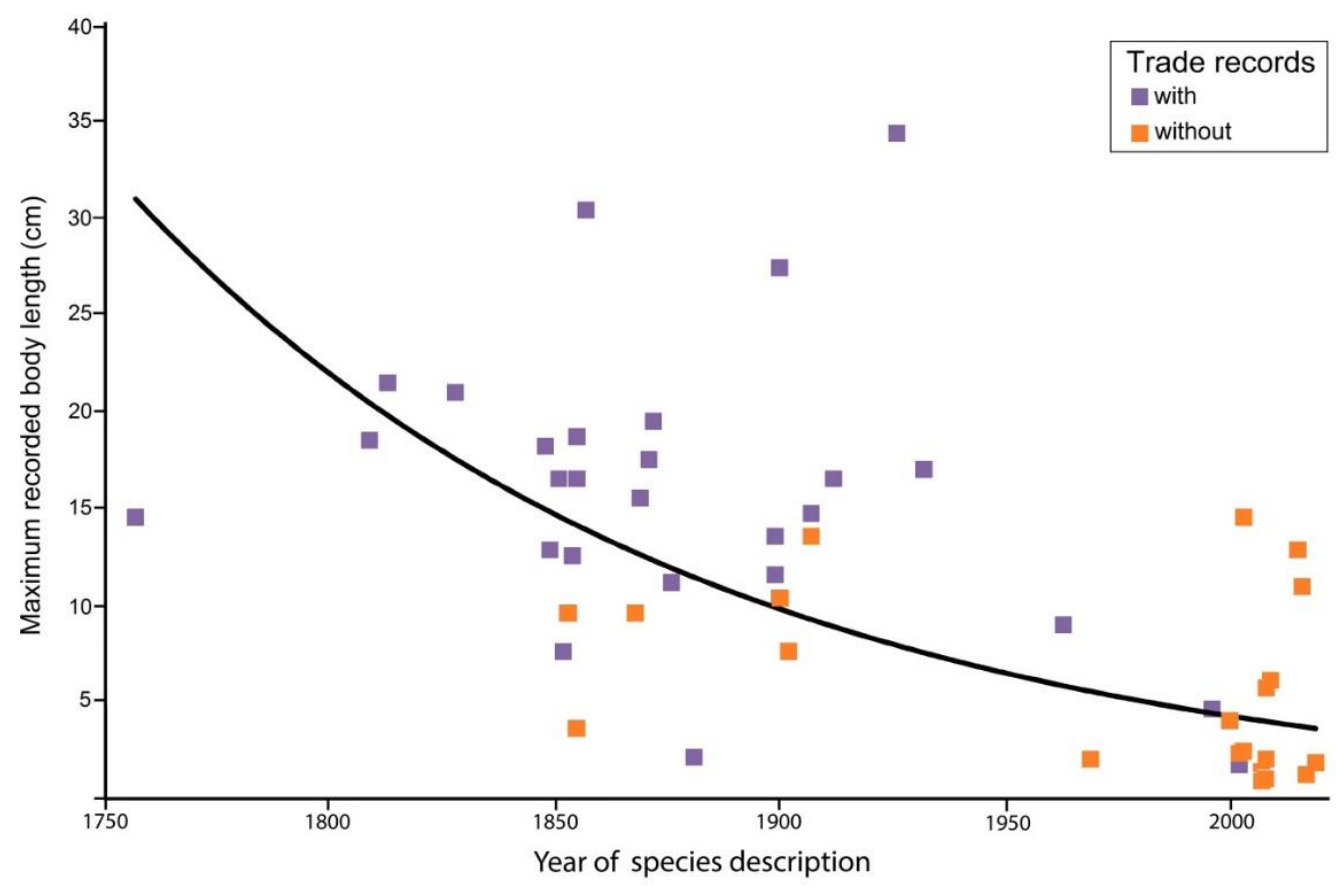

Figure 2. Maximum length of newly described Hippocampus species (1758-2020, $n=48)$, with and without trade records [69], based on data in Table 1, showing a tendency for additional new species to become exponentially smaller in size, approaching the function $\mathrm{y}=60.17 \times 10^{6} \times \mathrm{e}^{-0.01 x}$ (Pearson correlation coefficient, ln-transformed $(\mathrm{R}=-0.675, p<0.00001)$.

Large seahorse species that are commonly fished, such as $H$. reidi (Figure $3 b$ ), are overall less specific in their habitat requirements but share several traits with small congenerics, such as the use of camouflage and an immobile body posture while using the tail as holdfast $[29,108]$ (Figure $3 b$ ), but some species are able to change coloration as part of their courtship behavior $[109,110]$ or need for camouflage [103]. A few species are exceptional and show much interspecific variation in coloration, including bright tints $[29,111]$ and biofluorescence [96,112]. Various large seahorse species are commonly found in seagrass beds [113-118], and as they can be monitored easily by recreational divers as citizen scientists [119], they can also be handpicked by professional fishermen. A broad habitat spectrum, as seen in H. reidi [120-122], probably enhances a species' suitability as an aquarium pet. As seahorses are poor swimmers, the availability of a holdfast is an important habitat factor $[123,124]$, which may explain why some species have no problem in using artificial substrates to cling on [125-132]. 

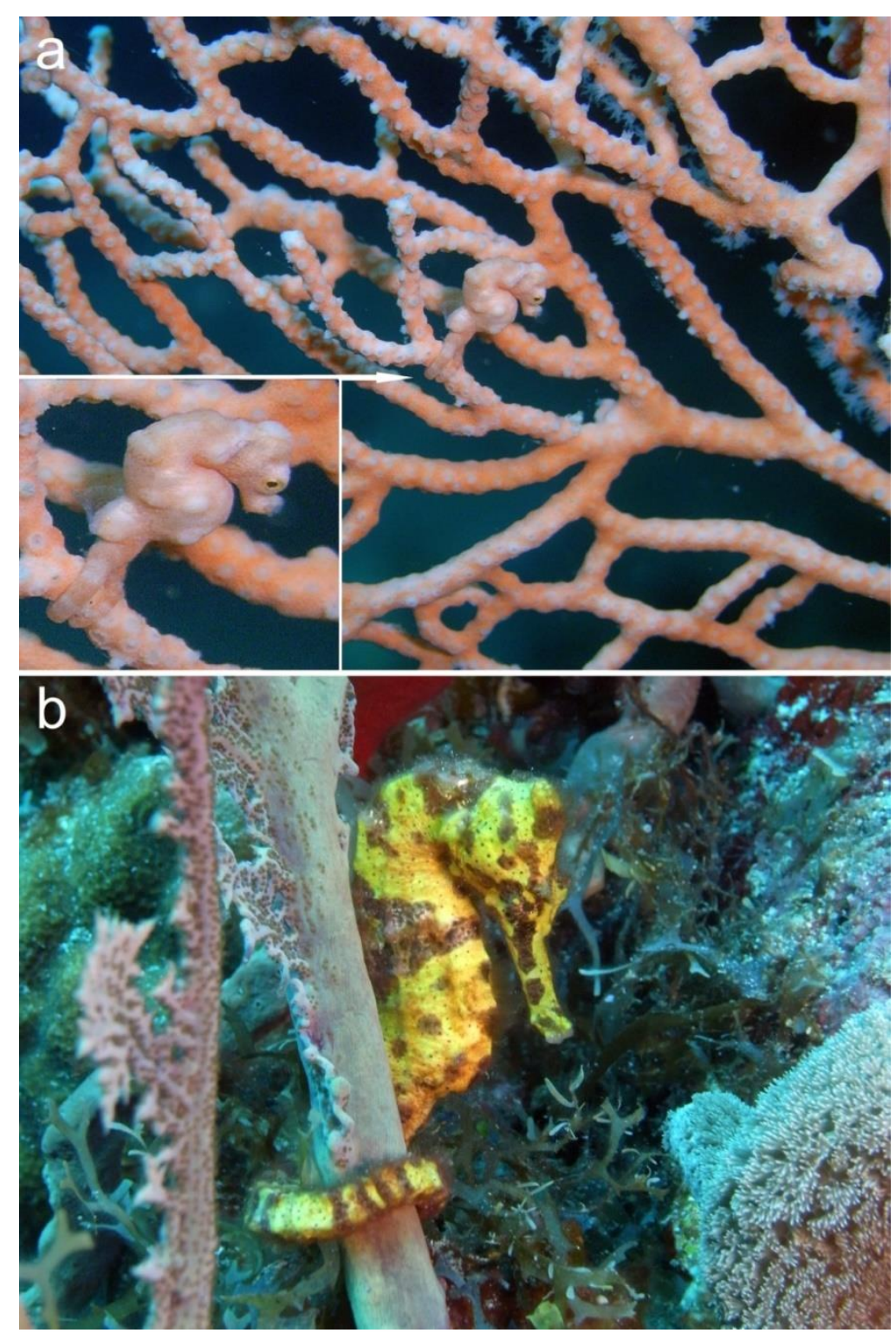

Figure 3. Two Hippocampus individuals clinging to gorgonian octocorals in their natural environment: (a) H. denise at Raja Ampat Islands, West Papua, Indonesia (2006); (b) H. reidi at St. Eustatius, Eastern Caribbean (2015). Photo credit: B.W. Hoeksema.

\section{Hippocampus Species in the International Aquarium Trade}

Regarding the trade of seahorses in the aquarium industry and those used as traditional medicine, there are differences in scale, species composition, source countries, and consumer countries, which can be found in primary sources, such as the CITES Trade Database [69] and also in published reports [133].

\subsection{Hippocampus and CITES}

For the present research, the presence of these species in the international aquarium industry was determined using the CITES Trade Database [69], as in some previous studies $[33,134,135]$. The data were analyzed to provide trade information based on export- and import-reported quantities of Hippocampus species and most important import and export countries, differences between countries, and trends over time. The search parameters in the database consist of year range, exporting and importing countries, source (e.g., wild-sourced or cultured specimens), purpose of the transaction (e.g., commercial, scientific, zoo), trade terms (e.g., live specimens, dead bodies), and taxon (species, genus). The 
quantities of the transaction could be either expressed in weight or number of individuals, but only number of individuals was used in the present analysis concerning live animals. Data extracted from the database were available for the years 1997-2018, but we need to keep in mind that not all data represent global trade before CITES, as those of 1997-2004 only denote trade reported by EU member states (seahorses have been listed on EU Annex D since 1997) and some voluntarily reports from other countries. Only data reported since 2004 are global in scope.

In our analyses, all importing and exporting countries and all trade purposes were included. Only "live" specimens were considered in the trade terms. Sources only included codes "W" (taken from the wild), "U" (unknown), "C" (captive-bred), and " $\mathrm{F}$ " (born in captivity as F1 generation from wild-caught parents F0). When a source is " $U$ " or not mentioned, the trade database assumes that it concerns " $\mathrm{W}$ ". This is most evident in preCITES data, when there was no recorded trade in cultured specimens (Table 2). Seahorses that were reared in captivity are considered cultured (coded as " $\mathrm{C}$ " and " $\mathrm{F}$ "). Numbers of seahorses that were ranched were negligible and therefore not taken into account. Reexports, although uncommon, were excluded from the analyses to prevent duplicates. For example, 200 specimens of $H$. zosterae $(\mathrm{W})$ were exported from the United States to the Netherlands in 2017 and re-exported to Mexico in 2018 [69]. Individuals of the same species were exported to Canada in 2010, Germany in 2012, South Africa in 2015, and returned to the United States in the same years [69]. The CITES trade database does not include data on domestic trade, mortality of seahorses in captivity, or cultivation in import countries.

Table 2. Import numbers (individuals) of live-traded Hippocampus species in the EU over 1997-2003 [69] (ranking 1 to 12). Hippocampus spp. = other species and unidentified. Source: $\mathrm{C}=$ captive-bred, $\mathrm{F}=$ born in captivity, $\mathrm{W}=$ wild-caught, $\mathrm{U}=$ unknown and unmentioned. Re-exports are excluded.

\begin{tabular}{|c|c|c|c|c|c|}
\hline Species & $\mathrm{C}$ & $\mathbf{F}$ & $\mathbf{W}$ & $\mathbf{U}$ & Total \\
\hline H. abdominalis (6) & 0 & 0 & 769 & 0 & 769 \\
\hline H. barbouri (11) & 40 & 0 & 0 & 0 & 0 \\
\hline H. comes (10) & 0 & 0 & 35 & 6 & 41 \\
\hline H. erectus (2) & 0 & 0 & 21,107 & 6632 & 27,739 \\
\hline H. hippocampus (3) & 0 & 0 & 1727 & 3838 & 5565 \\
\hline H. histrix (9) & 0 & 0 & 104 & 0 & 104 \\
\hline H. ingens (5) & 0 & 0 & 1 & 1000 & 1001 \\
\hline H. kelloggi (12) & 0 & 0 & 0 & 0 & 0 \\
\hline H. kuda (1) & 0 & 0 & 29,285 & 22,156 & 51,441 \\
\hline H. reidi (4) & 0 & 0 & 3557 & 1070 & 4627 \\
\hline H. spinosissimus (8) & 40 & 0 & 70 & 58 & 168 \\
\hline H. zosterae (7) & 0 & 0 & 233 & 0 & 233 \\
\hline Hippocampus spp. & 40 & 0 & 40,409 & 10,254 & 50,703 \\
\hline Total & 120 & 0 & 97,297 & 45,014 & 142,431 \\
\hline
\end{tabular}

Of the 48 recognized Hippocampus species, 27 are represented in the international aquarium trade (Table 1). According to EU import data, in 1997-2003 more than 142,000 live Hippocampus individuals were exported to the EU alone (Table 2). In 2004-2018, after CITES became effective, a total of almost 680,000 live Hippocampus individuals were recorded as import (Table 3) and more than 1,090,000 as export (Table 4). Export data are generally higher because countries are not obliged to report imports, although some source countries also do not report exports. In some cases, annual species numbers reported by an import country appear to be higher than those of the export country [69].

Before 2004, there was almost no trade in cultured specimens (Table 2), but this changed when CITES became effective (Tables 3 and 4). Among the cultured animals, several species were predominantly reported as $\mathrm{C}$ (e.g., H. reidi, H. abdominalis, and $H$. ingens) and others mostly as $\mathrm{F}$ (e.g., H. kuda, H. comes, and H. histrix), which may depend on the biology of the species or perhaps on the preferred cultivation method in the source countries. 
There were also shifts in species composition. In 2005-2013, H. kuda was by far the most important traded Hippocampus species, followed by H. reidi and H. comes (Figure 4). For some species, such as H. barbouri, H. histrix, H. kelloggi, and H. spinossimus, reported quantities were relatively large around 2004-2005. For a few species, it appears that the number of traded individuals was highest before 2004 (e.g., H. erectus and H. abdominalis) and gradually decreased after CITES became implemented (Figure 4).


Figure 4. Annual trade records of live seahorses based on import data of the 12 internationally most traded species in the periods 1997-2003 (pre-CITES records from the EU) and 2004-2018 (global) [69]: (a) high annual numbers; (b) lower numbers.

The most important difference in species composition between the aquarium trade and the traditional medicine market is that the first is richer in species [133]. Rare species 
are absent in both markets, but some additional species have a low market value as dried specimens because they are generally too small, such as H. mohnikei, which is widespread in Asia [136-138]. Some species are rarely traded alive but commonly traded as dried specimens, such as H. trimaculatus, which occurs in the central Indo-Pacific [139] and is fished in several Asian countries [38,139-143]. A number of species are much marketed both as live specimens (Tables 2-4) and dried material, such as H. comes, H. erectus, H. kelloggi, and H. kuda $[133,134,144]$.

Table 3. Import numbers (individuals) of the most live-traded Hippocampus species worldwide over 2004-2018 [69] (ranking 1 to 12). Hippocampus spp. = other species and unidentified. Source: $\mathrm{C}=$ captive-bred, $\mathrm{F}=$ born in captivity, $\mathrm{W}=$ wild-caught, $\mathrm{U}=$ unknown and unmentioned. Re-exports are excluded.

\begin{tabular}{|c|c|c|c|c|c|}
\hline Species & $\mathrm{C}$ & $\mathbf{F}$ & $\mathbf{W}$ & $\mathbf{U}$ & Total \\
\hline H. abdominalis (8) & 6748 & 0 & 243 & 156 & 7147 \\
\hline H. barbouri (5) & 5167 & 906 & 8235 & 0 & 14,308 \\
\hline H. comes $(3)$ & 6972 & 61,867 & 9480 & 5 & 78,324 \\
\hline H. erectus (7) & 179 & 1060 & 7684 & 160 & 9083 \\
\hline H. hippocampus (12) & 200 & 20 & 86 & 82 & 388 \\
\hline H. histrix (6) & 1037 & 100 & 8578 & 20 & 9735 \\
\hline H. ingens (9) & 3968 & 0 & 3146 & 8 & 7122 \\
\hline H. kelloggi (4) & 0 & 300 & 14,037 & 0 & 14,337 \\
\hline H. kuda (1) & 54,951 & 231,079 & 103,337 & 1065 & 390,432 \\
\hline H. reidi (2) & 105,357 & 1038 & 18,723 & 116 & 125,234 \\
\hline H. spinosissimus (11) & 627 & 80 & 3424 & 0 & 4131 \\
\hline H. zosterae (10) & 4 & 1448 & 2805 & 190 & 4447 \\
\hline Hippocampus spp. & 5919 & 1607 & 6997 & 123 & 14,646 \\
\hline Total & 191,129 & 299,505 & 186,775 & 1925 & 679,334 \\
\hline
\end{tabular}

Table 4. Export numbers (individuals) of the most live-traded Hippocampus species worldwide over 2004-2018 [69] (ranking 1 to 12). Hippocampus spp. = other species and unidentified. Source: $\mathrm{C}=$ captive-bred, $\mathrm{F}=$ born in captivity, $\mathrm{W}=$ wild-caught, $\mathrm{U}=$ unknown and unmentioned. Re-exports are excluded.

\begin{tabular}{cccccc}
\hline Species & C & F & W & U & Total \\
\hline H. abdominalis (4) & 26,732 & 60 & 165 & 828 & 27,785 \\
H. barbouri (5) & 6170 & 2354 & 14,630 & 0 & 23,154 \\
H. comes (3) & 30,690 & 110,986 & 13,185 & 0 & 154,861 \\
H. erectus (9) & 1509 & 505 & 9786 & 0 & 11,800 \\
H. hippocampus (12) & 24 & 0 & 20 & 0 & 44 \\
H. histrix (6) & 0 & 5650 & 14,637 & 0 & 20,287 \\
H. ingens (8) & 11,532 & 0 & 15,024 & 0 & 14,748 \\
H. kelloggi (7) & 0 & 0 & 60,372 & 0 & 15,024 \\
H. kuda (1) & 71,009 & 367,645 & 12,340 & 0 & 499,026 \\
H. reidi (2) & 291,464 & 0 & 7029 & 0 & 303,804 \\
H. spinosissimus (10) & 431 & 0 & 1880 & 0 & 7460 \\
H. zosterae (11) & 1644 & 194 & 6547 & 324 & 3718 \\
Hippocampus spp. & 3114 & 81 & $\mathbf{1 5 8 , 8 3 1}$ & $\mathbf{1 1 5 2}$ & 10,066 \\
\hline Total & $\mathbf{4 4 4 , 3 1 9}$ & $\mathbf{4 8 7 , 4 7 5}$ & & $\mathbf{1 , 0 9 1 , 7 7 7}$ \\
\hline
\end{tabular}

\subsection{Threat Status and Body Size of Hippocampus Species in the Aquarium Trade}

Various Hippocampus species (33\%) present in the trade are classified as "Data Deficient" (DD), which are mostly species that have been discovered in the last two decades (Table 1). This may indicate that abundances of these species are very low, sightings are rare, and that they may actually be endangered [145]. Most of the recently discovered species have an IUCN Red List status of Data Deficient (DD) or have not yet been evaluated (NE) (Table 1). The 12 most traded Hippocampus species in the aquarium industry 
(Table 2, Figure 4) are among the species that were discovered early, in the period 1758-1933 (Table 1). Eight of these species have the conservation status "Vulnerable" (VU).

Most species of no commercial value are relatively small and have been discovered recently, two factors that appear to be related (Figure 2). This is also reflected in a minimum size limit of $10 \mathrm{~cm}$ height proposed in fisheries [146-148], which is not relevant for most species that are not of commercial importance. It is plausible that species that have been discovered recently (Table 1) are not yet known in the international trade of ornamental fishes and have not been listed in the CITES Trade Database. Among the small species, the dwarf seahorse, H. zosterae, described in 1882 (Table 1), is an exception because it is among the 12 internationally most traded Hippocampus species (Tables 2-4; Figure 4). There is no export to the United States as this species is native to that country $[40,149,150]$.

\subsection{Life History Traits and Habitats of Hippocampus Species}

Whether Hippocampus species are suitable as aquarium pets depends on their life histories and whether they can survive outside their natural habitats. There are various special handbooks that give advice to hobby aquarists regarding the husbandry of seahorses [151-156], and some deal exclusively with the dwarf seahorse, H. zosterae [157-159]. Specific information on seahorse husbandry in public aquariums is also available $[103,160]$. Because the life span of seahorses is very short, varying from 1 to 5 years [29], aquarium owners have to replace individuals very quickly, either by new purchases or by breeding. The number of newborn young released from the male's brooding pouch varies between 5 and 2000, mostly depending on the body size of the species [29].

The absence of some Hippocampus species in the trade is related to their late discovery and their cryptic lifestyle (Section 2.2), but it is also possible that they are just too rare for wild capture [102] or that their habitat requirements are very specific and cannot be copied in an aquarium environment [103]. Because host occupancy rates were observed to be low in some symbiotic pygmy seahorses [97] and underwater photographers tend to disturb their natural environment $[161,162]$, it is fortunate that these species appear to be uncommon in the aquarium industry. In 2004-2006, 1800 individuals of $H$. denise were recorded as exported from Indonesia, whereas only 504 specimens were listed as imported in Europe and the United States [69]. In contrast, the dwarf seahorse, H. zosterae, can be found abundantly in shallow seagrass beds in the Gulf of Mexico and the east coast of Florida [30,163], where they can be collected with the help of nets $[40,149,150,164]$, which explains why they are available in the aquarium industry [157-159]. This species produces much offspring $[149,164]$, whereas $H$. denise in association with gorgonians shows low population densities [97,102] and a low reproduction rate [107].

Some larger species (at least $8 \mathrm{~cm}$ long) cannot be found in the international aquarium trade because they may be rare or occur in a relatively small distribution range. An example is $H$. camelopardalis, which has a restricted range in the southwestern part of the Indian Ocean $[30,165]$, although there is also an incidental record from northwestern India [166]. Another example is $H$. tristis, a relatively large and very rare species, which is endemic to southern Australia and only known from a few museum specimens and a recent photograph [73]. Other species with restricted ranges are H. sindonis, which is only known from Japan and Korea [167], and H. fisheri from the Hawaiian Islands [168] with some doubtful records from eastern Australia and New Caledonia [30]. The absence of these rare species in CITES trade records does not imply that they are never caught for the aquarium trade, although this is unlikely for the extremely rare $H$. tristis. Another explanation for the absence of trade records is that some species cannot be kept alive in aquariums, such as $H$. fisheri [169]. Some trade records are based on misidentifications, such as those of H. capensis, an endemic to South Africa [111,115,129] (Section 4.5). Sixty live specimens of this species were reported as export from South Africa: 30 captive-bred (C) to China in 2010 for education and 30 that were born in captivity to a zoo in Hong Kong in 2014. These records do not count as commercial trade [69]. 


\subsection{Sources of Live Hippocampus Spp.}

As trade numbers of seahorses at the species level for 1997-2018 are only available as import records, trends in source data (wild-caught vs. cultured) can only be analyzed for that period, but with a distinction between pre-CITES EU-only records and CITES global records (Figure 4). Importing countries appeared to be most consistent in reporting over that period. Before 2004, trade records of H. barbouri, H. histrix, H. ingens, H. kelloggi, $H$. $k u d a, H$. spinosissimus were close to zero. Later import records of these species increased and reached a peak. Hippocampus histrix, H. kelloggi and H. spinossimus reached this trade peak around 2005. Overall, trade in most species decreased over the years. Exceptions are $H$. abdominalis, $H$. ingens, and H. zostera. Hippocampus erectus and H. hippocampus show relatively high trade numbers before 2004 (before CITES), with a strong decline in trade after that year. Before CITES became implemented (before 2004), all live-traded Hippocampus individuals were sourced from the wild (Figure 5). A shift from wild-caught to captive-bred export became evident after 2004, when the regulation became implemented [50], although the quantity of wild-caught seahorses still dominated trade numbers. The turning point came around 2007, when the number of traded wild-caught seahorses started to decline and the quantity of traded cultured seahorses began to increase (Figure 5).

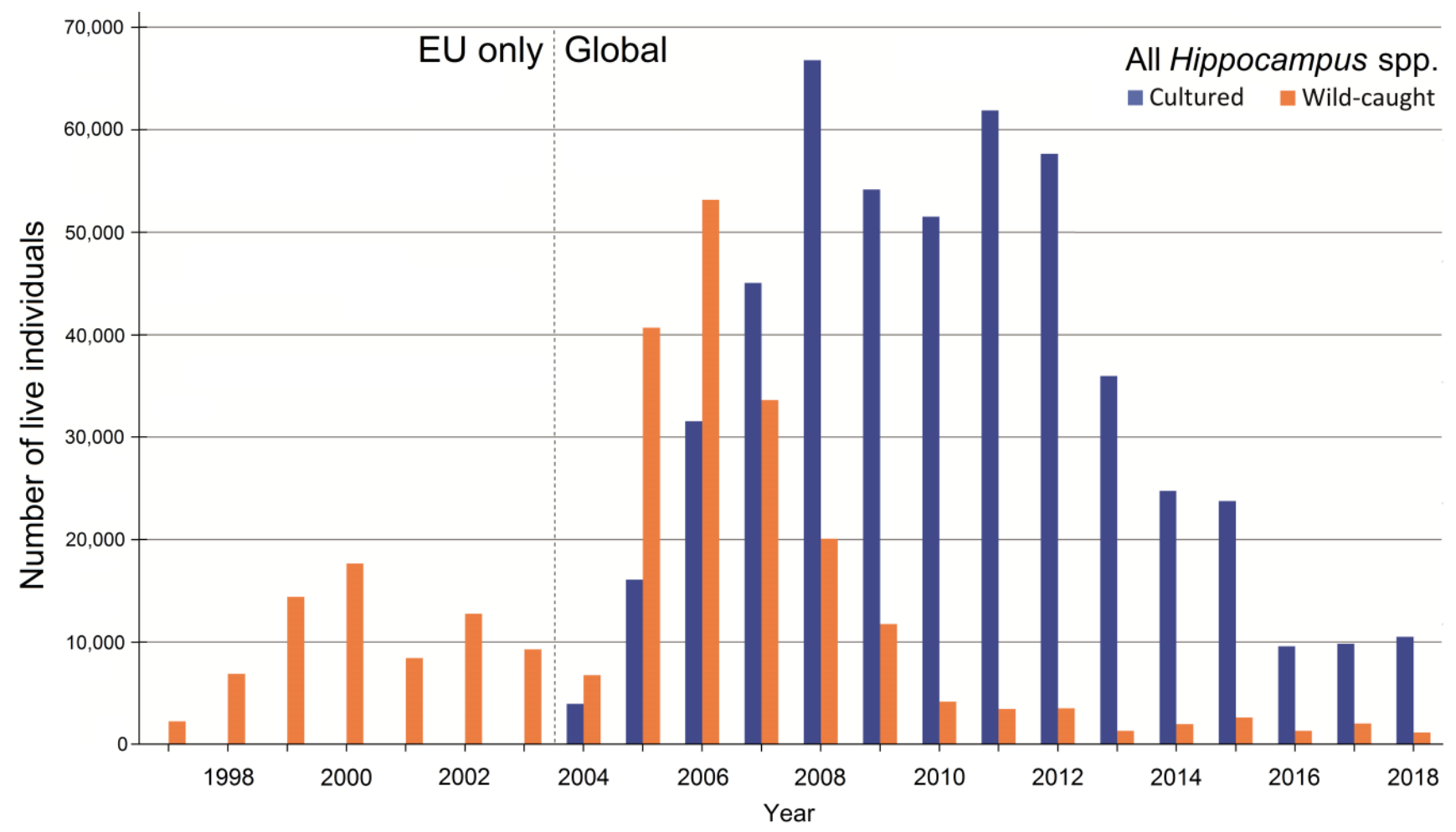

Figure 5. International trade in cultured $(\mathrm{C}+\mathrm{F})$ and wild-caught $(\mathrm{W}+\mathrm{U})$ Hippocampus specimens based on CITES import data for the period 1997-2018 [69]. Data from before 2004 concern the EU only.

For the whole period 1997-2018, most internationally traded live seahorses came from a cultured source (Tables 2-4). The majority of the specimens of H. kuda, H. reidi, H. comes, H. abdominalis, and $H$. ingens came from cultivation (Figure $6 \mathrm{a}-\mathrm{c}, \mathrm{i}, \mathrm{j}$ ), whereas the majority of individuals of H. barbouri, H. erectus, H. hippocampus, H. histrix, H. kelloggi, H. spinosissimus, and $H$. zosterae came from the wild (Figure $6 \mathrm{~d}-\mathrm{h}, \mathrm{k}, \mathrm{l})$.

In 2004-2018, Vietnam was the main exporting country of live Hippocampus, covering almost $50 \%$ of the traded individuals (Figure 7a). Since 2004, there was a substantial increase in cultured seahorses reported from this country, which could have been facilitated by advances in seahorse husbandry and captive breeding [170]. Foster et al. [33] suggest that this could partly be due to misreporting of wild-caught animals as captive-bred, 
intentionally or as a mistake. The possibility of continued illegal and unregulated trade resulting in poor-quality trade data makes it difficult to assess the results of seahorse culture on the exploitation of wild populations [51]. The majority of traded seahorses from Indonesia and Brazil were wild-caught. For most source countries, it is unclear how many seahorse individuals are caught for the domestic market or for private use, depending on whether it is allowed to take live animals (with or without permits).
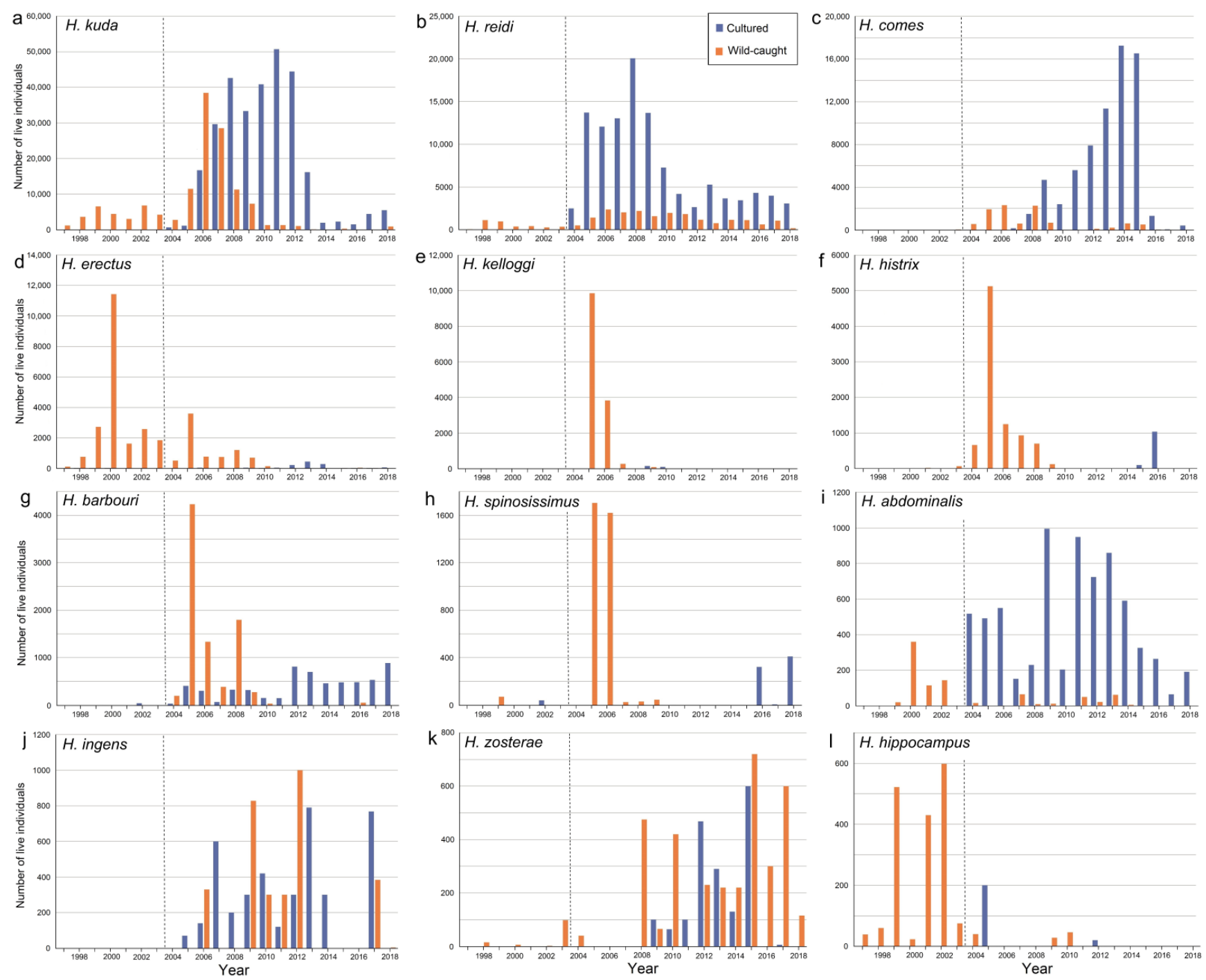

Figure 6. Import data for the 12 most traded Hippocampus species in the period 1997-2018 [69]. Data from before 2004 concern the EU only. Cultured $=\mathrm{C}+\mathrm{F}$; wild-caught $=\mathrm{W}+\mathrm{U}$.

The United States was by far the largest importer of live Hippocampus (Figure $7 \mathrm{~b}$ ), while it also has domestic trade of the native H. zosterae [171,172]. Almost a third of the imported seahorses came from a cultured source. Apart from the US, Canada, Japan, and Singapore, other important importing countries are located in Europe. For the EU single-market, trade among member states is not recorded in the CITES trade database.

\subsection{International Trade in Live Animals vs. Dead Bodies}

Trade in live seahorses is as young as the international aquarium industry, catering to hobbyists all over the world, whereas the use of seahorses as traditional medicine has its roots in China [173,174]. With growing imports from other countries and Chinese consumers migrating to other countries, this market became larger and more international. Although most seahorses in the international trade are dried, in some source countries 
the trade in live specimens for the international aquarium industry has been a threat for natural populations before CITES became effective [30], and many specimens are still wild-caught (Tables 3 and 4). CITES trade records for live Hippocampus individuals and (dried) dead bodies show striking differences in composition and timing (Table 1). While 27 traded species have been recorded as live animals, only 18 have also been listed as dried bodies [33]. With the exception of H. kelloggi, the first trade record of each species concerned living animals, whereas dead bodies were recorded one to several years later, suggesting that trade in live animals is more transparent than that of dried specimens.
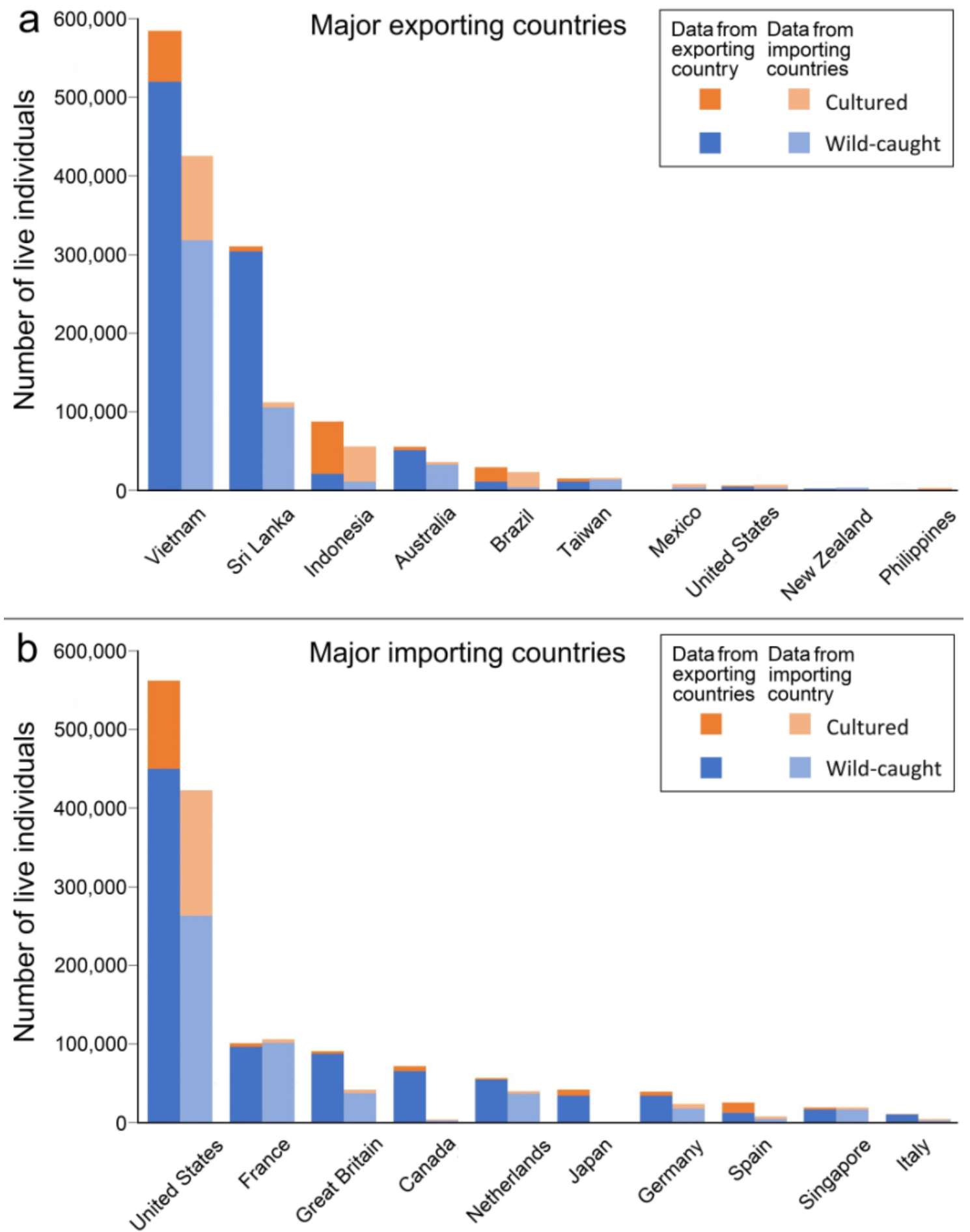

Figure 7. Trade in live Hippocampus individuals by source category, wild-caught $(\mathrm{W}+\mathrm{U})$ or cultured $(\mathrm{C}+\mathrm{F})$, for the 10 most important exporting (a) and importing (b) countries in 2004-2018 [69]. A distinction is made between data from exporting countries and importing countries. 
The international trade of Hippocampus is divided into two separate markets. For instance, $H$. algiricus from West Africa is rare in the aquarium trade and commonly sold as medicine $[33,175]$. Most early import data (1997-2003) are pre-CITES records from the $\mathrm{EU}$, which are mostly unrelated to the medicine market (Section 3.1). However, it is likely that since 2004, large proportions of dead seahorses in the international trade have also not been reported $[176,177]$. Because of their dry conservation, they are of low weight and they can be densely packed (in concealing packaging), which makes them easy to store and inexpensive to ship. Nevertheless, in the Philippines, dried seahorses appear to provide 2-4 times better prices to fishermen than live individuals [41]. An increase in the market price of dried seahorses was noticed after the CITES listing in 2002 [178].

Trade in live specimens is more difficult because the animals need to be packed in water and shipped as quickly as possible (as air freight) in order to prevent mortality $[179,180]$. The overall trade in Hippocampus spp. showed a decrease in the issue of export permits after CITES became effective in 2004, but this did not concern live individuals (Figure 5) as much as dried specimens [50]. Possible explanations are (1) some countries were unable to shift towards sustainable trade, (2) there was a lack of support because not enough people were involved in the fisheries, or (3) the export volume might have been too low [50]. This trend is particularly shown by $H$. histrix, $H$. kelloggi, and $H$. spinosissimus, almost all of which were wild-caught. The declining trend in trade volume may also have been the result of declining seahorse populations instead of trade regulations [50]. Therefore, depending on the species, (illegal) trade of dried specimens may also affect seahorse populations exploited for the international aquarium trade.

\section{Aquaculture of Hippocampus}

Less than $5 \%$ of the ca. 1500 marine ornamental fish species in the international aquarium trade are kept in aquaculture [181,182], and various Hippocampus species (Figure 6) are part of this minority. The cultivation of Hippocampus spp. is currently only serving the trade in ornamental fishes, as attempts of large-scale farming for the traditional medicine markets have not been successful [44]. As mentioned in Section 3.1, the trade data indicate large differences among species in source preference for either breeding in captivity $(C)$ or born in captivity (F), which may depend on whether species can be cultivated easily or not (Tables 3 and 4 ).

\subsection{Methods of Seahorse Aquaculture}

Aquaculture of seahorses can be divided into three parts: production of live prey (usually Artemia sp. and copepods), keeping of breeders, and maintenance of a nursery facility for juveniles as they grow into an appropriate size $[43,44,51,181,183]$. There is no larval breeding stage because fertilized eggs are incubated inside the male's pouch [43,184-187]. Seahorse species in captivity usually become sexually active at ages of around 3 to 6 months. During the breeding season, they maintain a long-pair bond and are generally monogamous in a single breeding cycle; therefore, selection of the male is important for the fitness and survival of the young [109,114,183]. Hatching periods usually vary between 14 and 40 days but can be shorter at high temperatures [188]. The pygmy seahorse $H$. denise has shown a gestation period of only 11 days in captivity [107]. Many seahorse species have multiple batches of eggs during a breeding season, when temperatures and photoperiods are kept constant in culture operations [189].

In terms of husbandry, seahorses are sensitive to changes in water chemistry. It is therefore important that the aquarium habitat mimics their natural habitat [43]. Moreover, the keeping of good broodstock and the selection of healthy mating pairs are very important. Seahorses that are kept in optimal conditions will spawn naturally [43]. The diet of seahorses in the wild predominantly consists of small pelagic crustaceans, such as amphipods, copepods, and mysids [190-196], but nematodes are also important prey, depending on the habitat $[197,198]$. Prey shape and size are very much determined by the form of the seahorse head, in particular the long and tubular snout, and by their special 
feeding behavior, including suction and pivot feeding [199-205]. Most seahorse culture operations rely on cultured live food such as Artemia (brine shrimp), copepods, mysid shrimps, rotifers, and amphipods, but some also rely on wild-collected food [206-208]. Studies have demonstrated a variety of diets for different species, but enriched food seems to benefit both juvenile and adult seahorses and their reproduction success $[51,209,210]$. Skin color in seahorses, which can be variable in some species $[109,110,211]$, is an important attribute in the aquarium industry and can depend on diet [2,212]. Individuals with the brightest color are sold for prices up to USD 500, or even higher in exceptional cases [43].

\subsection{Challenges in Seahorse Aquaculture}

Although aquaculture of seahorses is often thought of as a commercial venture and as a means to reduce pressure on wild populations, it could also result in negative effects on the marine environment and its populations. Firstly, the economic viability of seahorse aquaculture poses a concern. As rearing brood to market size can take months, it is still unclear whether the aquaculture industry can provide sufficient volumes of Hippocampus specimens in a cost-effective way to supply the demand [213]. Low survivorship of juveniles is a major problem in seahorse aquaculture $[63,189,214,215]$. Moreover, the acceptability and price of cultured seahorses are matters that need to be determined beforehand [216]. Economic constraints include costs of local electricity and water and heating unit efficiency [63]. Until production costs can be optimized or market prices rise, expansion of seahorse cultivation can be limited in developed countries. In developing countries, on the other hand, the main challenge of seahorse aquaculture is related to technical problems, such as rearing and diseases [51]. Under farmed conditions, seahorses experience stress, which increases their susceptibility to infection and diseases [217].

A variety of seahorse diseases have been reported to cause mass mortalities and damage to aquaculture operations, including bacterial, fungal, viral, parasitic, and noninfectious diseases [182,218]. For example, vibriosis is a bacterial infection found in aquarium and aquaculture operations worldwide, causing severe ulcers in the skin of species such as H. kuda [218-220], while other microbes can cause enteritis, which is also found in other cultured fish species [221-225]. Thus, apart from the problems these pathogens create for current aquaculture operations and the extra control and prevention measures that are required, the pathogens pose a danger to other fish species [218]. This highlights the requirement of further research into potential drugs and the development of disease resistance in seahorses.

The need for proper maintenance and water changes, water quality, cleaning, and feeding regimes are extremely important in aquaculture [182,226]. Most aquaculture operations rely on the use of intensive monoculture systems, which means that the animals are kept in aquaria under controlled water parameters and depend on exogenous feeding to survive. Feeding can create various challenges regarding the type of diet for different species at different life stages [227]. Moreover, cultivation of high volumes of live food can be inefficient, expensive, and difficult, while it also can facilitate the introduction of diseases $[63,66,67,228-230]$. Furthermore, as most culture operations have open or semiclosed systems, problems related to effluent, water use, and escapes are very common in seahorse cultivation [51]. Aquaculture can therefore also result in potential damage to the marine environment. Lastly, the success of aquaculture practices also partly depends on how well it can accommodate alternative livelihoods for subsistence fishers in source countries $[51,55,231]$. Aquaculture is likely to be most effective in reducing pressure on wild populations if seahorse fishers in source countries are facilitated to shift towards a more sustainable seahorse trade.

\subsection{Aquaculture in Different Source Countries}

CITES Parties strive to record all transactions, but some countries (e.g., Sri Lanka) recorded large volumes of seahorses for some years while having no records for other years [33]. According to the CITES trade data [69], the number of captive-bred seahorses 
increased after the listing of Hippocampus species in CITES, especially for Vietnam and Sri Lanka. Even though the export of live Hippocampus individuals in Vietnam is well documented in the CITES database, it appears that there are some doubts concerning the renaming of cultured species [232]. After the ban on the export of $H . k u d a$ in 2013, reported exports of $H$. kuda born in captivity (source code F) decreased by $99 \%$, whereas exports of $H$. comes (with F) increased 5 times. However, Vietnamese companies reported to have only produced low numbers of $H$. comes in the past. Moreover, just one aquaculture farm remained in operation and reported that they only cultured $H$. kuda. It seems that Vietnam clearly has been dependent on wild-caught seahorses for its export, whereas its import of live seahorses from other countries, such as Cambodia and Indonesia [133,232], has only rarely taken place [69]. Aquaculture facilities struggle to close the life cycle. They primarily produce F1 generation - the offspring is born in captivity, but pregnant males are caught in the wild. Therefore, it appears that the commercial culture of seahorses is still reliant on wild broodstock [232].

In Sri Lanka, researchers were able to establish a successful culturing protocol to breed H. reidi artificially. Hettiarachchi and Edirisinghe [233] describe broodstock management and rearing of Hippocampus juveniles and how to develop various color varieties. The broodstock feeding consisted of a mixed diet of enriched Artemia, mysid shrimps, and estuarine copepods. After 5-6 months, $H$. reidi individuals reached marketable size with mean survival rates at $65 \pm 5 \%$. By culturing non-native Hippocampus reidi, culture operations in Sri Lanka were able to prove that their export was captive-bred and thus allowed to continue export under CITES regulations [28].

Indonesia is the main exporter of $H$. barbouri (W), and exporters have indicated a willingness to shift towards seahorse culture [231]. A study on the success of implementing a culture project for $H$. barbouri in Indonesia found that aquaculture could not fully replace fishing in livelihoods but instead could partly supplement and diversify fishing and collecting from the wild [231]. Exporters had great interest in cultivated seahorses, as they also experienced the results of depleted marine environments, but the economic feasibility and aquaculture technology need to be improved. Moreover, aquaculture needs to be part of a larger and multifaceted approach that also targets and improves habitat protection and restoration, makes livelihoods and stakeholders more diverse, and improves the enforcement of fishing regulations [234].

For some countries, such as the Philippines, the live trade of seahorses ceased after the listing of Hippocampus species under CITES. No records are known of illegal or unreported trade. However, according to Foster et al. [22], the Philippines used to run some seahorse aquaculture companies in the past and continues to show interest in this industry, leaving room for potential aquaculture operations in the future.

\subsection{Opportunities for Hippocampus Aquaculture}

When aquaculture operations struggle with diet and disease, systems provisioning natural food might be more efficient and could enhance results [181]. One example is an integrated multitrophic aquaculture system (IMTA) that uses the cage-culture approach. Fonseca et al. [213] developed a system in which H. reidi individuals were cultured in free-moving cages inside a shrimp and oyster farm, proving to be technically feasible, profitable, and resilient.

Another example concerns a cage culture of $H$. reidi that was set in mangrove estuaries in Brazil [235]. When cages with seahorses are installed in mangrove ecosystems, the fish have direct access to their natural prey $[29,236,237]$. In the Philippines, artificial light was used in an experiment to lure copepods into cages containing H. barbouri in order to provide the seahorses with prey [238]. Another study demonstrated a successful integrated eco-aquaculture system in which $H$. kuda individuals were cultured in artificial ponds with fertilized water to nourish natural seahorse food and co-cultured seaweed in order to regulate water quality and light and to provide holdfasts and prey for seahorses [239]. Another study showed that integrating macroalgae in the production system was beneficial 
for the survival and growth rate of juvenile H. erectus [240]. These low-cost culturing methods offer numerous opportunities for subsistence fishers and could potentially increase environmental and social sustainability in low-income communities. Commitment of local stakeholders can contribute to reduced reduction of the illegal, unregulated, and undeclared collection of wild seahorses [181]. However, there are also some constraints related to these production systems, such as creating an ecological imbalance in estuaries, net blockage, predators, and escapees [235].

Over the years, seahorse aquaculture methods and techniques have improved, but this sector is still facing many challenges, such as cost-effective production, diet, and diseases. Seahorse aquaculture still mainly relies on wild broodstock to continue its culture operations [51,57]. This will become effective if subsistence fishers are encouraged to shift towards a more sustainable way of seahorse trade. The marine ornamental fish industry is a great opportunity for source countries to become involved in community-based conservation-focused aquaculture initiatives $[231,241]$. Therefore, seahorse aquaculture should be encouraged to focus on the cultivation of local species and operate in the source countries.

Unless seahorse fishers can derive enough income from aquaculture to sustain their livelihood, there will be no incentive to protect their biological resources and shift towards more sustainable measures [51,216]. By involving local communities in aquaculture practices, it will be easier to reduce the illegal trade of wild seahorses and increase ecological and social sustainability [181]. In recent years, more research has been done on developing low-cost aquaculture techniques such as IMTA aquaculture systems that use the cageculture approach. These newer aquaculture methods are promising as they are low-cost, feasible, profitable, resilient, and most of all can be more easily implemented in important export countries.

Even if there is a shift towards aquaculture operations, this will not motivate fishers to prevent the capture of seahorses as bycatch because they still use nonselective fishing methods such as trawling $[140,242]$. Therefore, increased efforts are needed to improve seahorse-fishing methods [23]. Since CITES records cannot keep track of domestic trade; illegal, unregulated, or unreported exports; or misidentifications [144,243,244], it is important that representative trade field surveys are maintained in areas that are known to export wild seahorses [245].

To better understand why some seahorses are more popular in the aquarium trade, it is also important that more research be done on the relationship between, for example, the length of seahorse species and their presence in trade. Moreover, to improve differentiating between cultured and wild-caught seahorses, tagging methods should be developed for captive-bred seahorses along with a certification and registration system for aquaculture facilities in which they are bred [51]. Furthermore, efforts should be made to motivate aquarium hobbyists to choose cultured seahorses instead of wild-caught ones, as long as these come from original source countries [51]. Lastly, there are still some constraints with IMTA systems that should be dealt with in order to develop a trustworthy cultivation protocol. Economic, environmental, and social sustainability should be assessed to ensure that cage culture is realistic and sustainable [235].

Public awareness of the diversity of seahorses and their reproductive biology, ecology, and iconic shape may also play a role in their conservation. The number of scientific publications on seahorses published each year is growing steadily (around $40 \mathrm{yr}^{-1}$ in 2011-2016), most of them dealing with Hippocampus kuda, H. guttulatus, H. reidi, H. abdominalis, H. erectus, H. hippocampus, and H. trimaculatus [181]. Interestingly, among these most-studied species, H. guttulatus and H. trimaculatus are not among the 12 species that are most common in the aquarium trade (Tables 2-4). Among these 12, seven are not well investigated: H. comes, $H$. barbouri, H. kelloggi, H. histrix. H. ingens, H. zosterae, and H. spinosissimus. In other words, there is a discrepancy between seahorse species popular in trade and science, with some traded species appearing to be understudied. 
Fishers can be a valuable source of useful information regarding the trade and aquaculture of seahorses, not only for scientists but also for tourists [143,246-250]. Public aquariums can help in the development of seahorse breeding, which is particularly important for endangered species [57,231,251-255]. Thanks to aquarium experiments, we know more about the reproduction of pygmy seahorses [103,107], but little is known about the lifespan of these rare species because they are hard to keep [104]. Public aquariums can also be used to study stress displayed by seahorses in captivity [251]. Although it may seem controversial, hobby aquarists and the aquarium industry can assist in the research on seahorse husbandry and conservation [255-257].

\subsection{Use of Molecular Tools in Hippocampus Diversity Research}

Animals and plants in the international trade, their organs or body parts, and particular products derived from them may be difficult to identify based on morphological characteristics alone. This problem is also recognized in the international trade of seahorses, with less than $10 \%$ of the specimens consisting of live animals and the rest of dried carcasses that are traded in large quantities, possibly composed of mixed species [258]. One of the latest developments in scientific research on the diversity of seahorses concerns the identification of specimens with the help of modern molecular techniques.

DNA analyses of various CITES-listed species groups have been performed on specimens found in markets or in international shipments, which helped to identify them at the species level. Since 2003, this technique became known as barcoding and started by using the universal mitochondrial gene cytochrome $c$ oxidase I (COI) as a marker [259]. Recently, new technologies have allowed the development of more specific markers and studies of entire genomes [260]. It is a prerequisite that material used as original reference should be identified by taxonomic experts before they become deposited in barcoding libraries (such as GenBank) and that these libraries are as complete as possible [256,261].

There are many examples of barcoding applied to CITES-listed taxa, most of which concern terrestrial plants [262-267] and vertebrates [268-272]. Barcoding of marine animals in the international trade has been widely applied to sharks [273-279], for which advanced genetic technologies are available [280]. Regarding the international marine aquarium trade, identification with the help of barcoding has been applied only to an illegally traded scleractinian coral, which was published in 2020 [281], whereas the need for the barcoding of marine ornamental fish species was already promoted in 2009 [282].

Molecular studies on Hippocampus species are not scarce, involving 35 of 48 species (Table 5). The first paper in which genetics was applied to distinguish seahorse species was a study by Lourie et al. in 1999 [32], which was based on specimens sampled from Vietnamese markets. 



aquarium trade, $¥=$ in traditional medicine $[69,133]$.

\begin{tabular}{|c|c|c|c|c|c|c|}
\hline \multirow[t]{2}{*}{ Species Name } & \multirow[t]{2}{*}{ Geographical Range } & \multicolumn{5}{|c|}{ Application of Molecular Analyses } \\
\hline & & $\begin{array}{l}\text { Barcoding/ } \\
\text { Genomics }\end{array}$ & $\begin{array}{l}\text { Forensics/ } \\
\text { Conservation }\end{array}$ & $\begin{array}{c}\text { Phylogeny } \\
\text { Reconstructions }\end{array}$ & Phylogeography & Functional Genetics \\
\hline H. abdominalis $\$ \geq$ & $\begin{array}{c}\text { SW Australia, New Zealand } \\
{[165,347,348]}\end{array}$ & $1[283]$ & $1[32]$ & $\begin{array}{c}13[186,287,305,308, \\
309,323,331-337]\end{array}$ & $2[347,348]$ & $\begin{array}{c}3[128,361 \\
362]\end{array}$ \\
\hline H. algiricus $\$ ¥$ & West Africa $[39,165]$ & $1[283]$ & $1[320]$ & $\begin{array}{c}11[288,289,295,299,302, \\
323,333,335,338-340]\end{array}$ & $1[339]$ & - \\
\hline H. angustus $\$ ¥$ & N Australia, South P.N.G. [165] & - & - & $3[322,335,341]$ & - & $1[363]$ \\
\hline H. barbouri $\$ ¥$ & $\begin{array}{c}\text { Central Indonesia, } \\
\text { Philippines } \\
{[165,341,342]}\end{array}$ & $3[284,285,344]$ & $4[321-324]$ & $\begin{array}{c}24[186,284,287,288,299 \\
302,305,308,309,314 \\
315,317,322,323,333- \\
338,341,343,344,380]\end{array}$ & $2[341,342]$ & - \\
\hline H. bargibanti & Central Indo-West Pacific [165] & $1[83]$ & - & $4[42,331,334,335]$ & - & - \\
\hline H. breviceps $\$$ & Southern Australia [165] & $1[286]$ & - & $5[42,76,323,335,338]$ & - & - \\
\hline 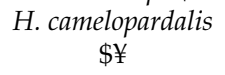 & SW Africa [165] & $1[287]$ & 1 [325] & $\begin{array}{c}7[287,295,305,323 \\
325,335,338]\end{array}$ & - & - \\
\hline H. capensis & $\begin{array}{l}\text { Southern tip of Africa } \\
{[165,339,349,350]}\end{array}$ & $\begin{array}{c}4[283,288, \\
289,350]\end{array}$ & $\begin{array}{c}3[320,324, \\
325]\end{array}$ & $\begin{array}{c}11[288,289,295,305, \\
309,323,325,335, \\
338,339,345]\end{array}$ & $\begin{array}{c}3[339,349, \\
350]\end{array}$ & - \\
\hline H. casscsio & South China Sea (SE China) [82] & $3[82,289,344]$ & - & $3[82,289,344]$ & - & - \\
\hline H. colemani & Lord Howe Is., E Australia [165] & - & - & - & - & - \\
\hline H. coronatus \$ & Japan, South Korea $[72,165]$ & - & - & $6[72,76,323,333,335,338]$ & - & $1[364]$ \\
\hline H. dahlia & N, E Australia [165] & - & - & - & - & - \\
\hline H. debelius & N Red Sea (Gulf of Suez) [78,165] & - & - & - & - & - \\
\hline H. denise $\$$ & Central Indo-West Pacific [165] & $2[83,283]$ & & $2[331,334]$ & - & - \\
\hline H. erectus $\$ ¥$ & $\begin{array}{l}\text { W Atlantic, Caribbean Sea } \\
{[165,339,340,351,352]}\end{array}$ & $6[284,293-297]$ & $1[324]$ & $\begin{array}{c}23[76,186,284,287,288, \\
295,299,302,305,311, \\
314,315,317,322,323, \\
332,333,335,337- \\
339,343,380]\end{array}$ & $\begin{array}{c}4[339,340, \\
351,352]\end{array}$ & $\begin{array}{c}6[365- \\
369,382]\end{array}$ \\
\hline H. fisheri & Hawaii $[165,168,339]$ & $1[168]$ & - & $\begin{array}{c}6[308,309,335,336 \\
339,340]\end{array}$ & 1 [339] & - \\
\hline H. guttulatus $\$ ¥$ & $\begin{array}{l}\text { W Europe, Mediterranean, } \\
\text { Black Sea }[165,339,353]\end{array}$ & $1[298]$ & 4 [326-329] & $\begin{array}{c}8[295,323,333-335 \\
338-340]\end{array}$ & $2[339,353]$ & $4[370-373]$ \\
\hline H. haema & Japan, South Korea [72] & - & & $2[72,333]$ & - & - \\
\hline
\end{tabular}


Table 5. Cont

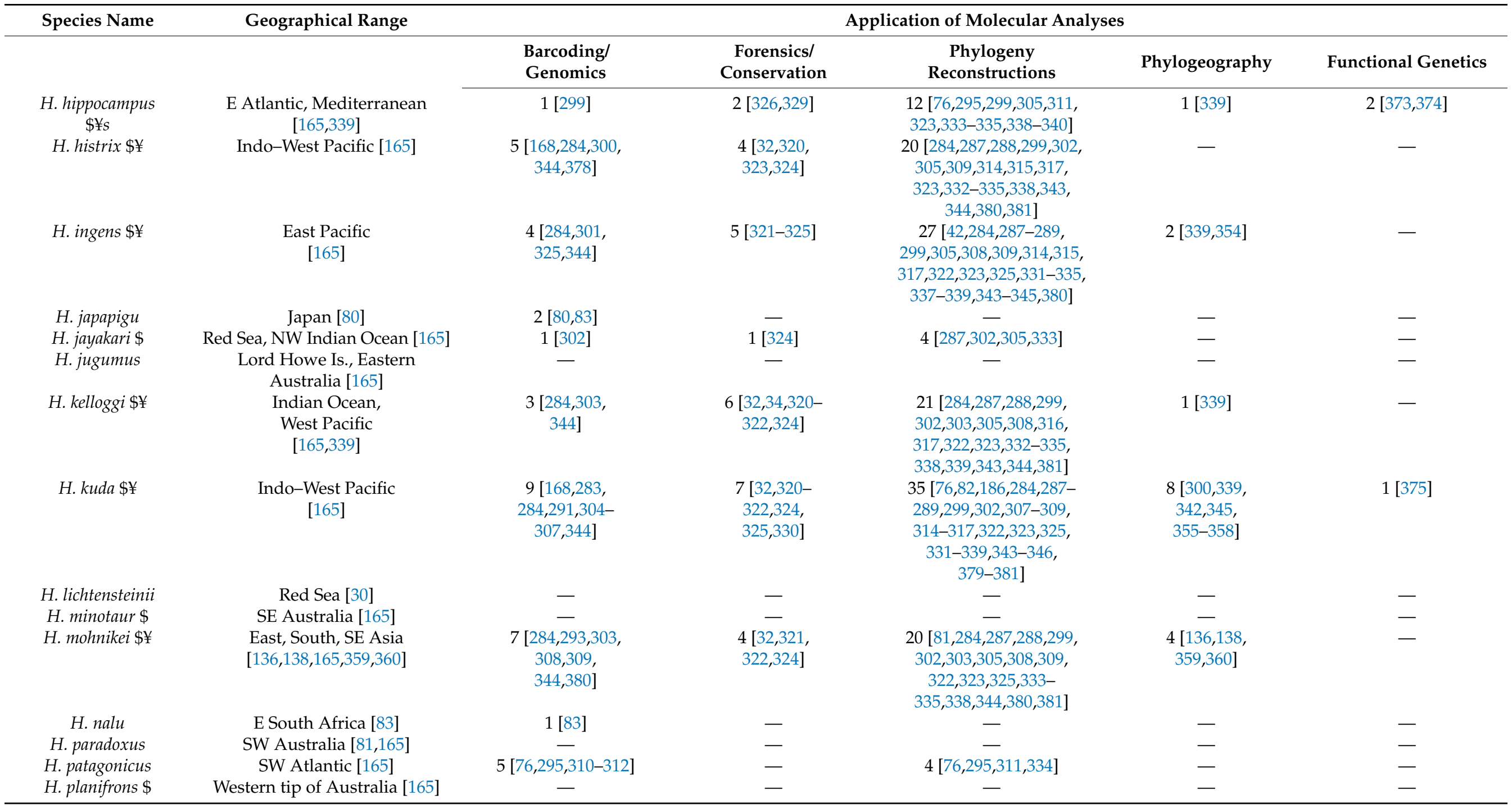


Table 5. Cont.

\begin{tabular}{|c|c|c|c|c|c|c|}
\hline \multirow[t]{2}{*}{ Species Name } & \multirow[t]{2}{*}{ Geographical Range } & \multicolumn{5}{|c|}{ Application of Molecular Analyses } \\
\hline & & $\begin{array}{l}\text { Barcoding/ } \\
\text { Genomics }\end{array}$ & $\begin{array}{c}\text { Forensics/ } \\
\text { Conservation }\end{array}$ & $\begin{array}{c}\text { Phylogeny } \\
\text { Reconstructions }\end{array}$ & Phylogeography & Functional Genetics \\
\hline H. pontohi & Central Indo-West Pacific [165] & $2[80,83]$ & - & $1[331]$ & - & - \\
\hline H. pusillus & New Caledonia [165] & - & - & - & - & - \\
\hline H. reidi $\$ ¥$ & $\begin{array}{c}\text { W Atlantic, Caribbean Sea } \\
{[165,339]}\end{array}$ & $\begin{array}{c}4[283,295,313 \\
314]\end{array}$ & $2[324,377]$ & $\begin{array}{c}25[42,76,287- \\
289,295,299,302,305,308, \\
309,314,317,323,325,331 \\
333-335,337-339 \\
343,345,380]\end{array}$ & $1[339]$ & $2[365,375]$ \\
\hline H. satomiae & Eastern Indonesia [165] & - & - & - & - & - \\
\hline H. sindonis & Japan, South Korea $[72,163]$ & - & - & $5[72,287,305,333,335]$ & - & - \\
\hline $\begin{array}{l}\text { H. spinosissimus } \\
\$ ¥\end{array}$ & $\begin{array}{c}\text { Central Indo-West Pacific } \\
{[165]}\end{array}$ & $\begin{array}{c}4[284,315-317, \\
344]\end{array}$ & $\begin{array}{c}6[32,34,320- \\
322,324]\end{array}$ & $\begin{array}{c}17[284,287,288,299,302 \\
305,315-317,323,333- \\
335,338,339,344,381]\end{array}$ & $\begin{array}{c}3[339,342, \\
358]\end{array}$ & - \\
\hline H. subelongatus \$ & SW Australia [165] & $1[286]$ & - & $6[308,314,323,335,338,341]$ & - & $1[361]$ \\
\hline $\begin{array}{l}\text { H. trimaculatus } \\
\qquad \$ ¥\end{array}$ & $\begin{array}{c}\text { Central Indo-West Pacific } \\
{[139,165,300,342,356,358,360]}\end{array}$ & $\begin{array}{c}4[284,307,318] \\
{[344]}\end{array}$ & $\begin{array}{c}6[32,34,320,321] \\
{[322,324]}\end{array}$ & $\begin{array}{c}24[284,287,288,299,302 \\
305,307-309,314,315 \\
317,322,323,325,331 \\
333-335,338,343 \\
344,380,381]\end{array}$ & $\begin{array}{c}6[139,300,342, \\
356,358,360]\end{array}$ & - \\
\hline H. tristis & Southern Australia [73] & - & - & - & - & - \\
\hline H. tyro & Seychelles [165] & - & - & - & - & - \\
\hline H. waleananus & Eastern Indonesia [78] & - & - & - & - & - \\
\hline H. whitei $\$ ¥$ & $\begin{array}{l}\text { S, E Australia, P.N.G., } \\
\text { Solomon Is. [165] }\end{array}$ & $2[283,319]$ & - & $\begin{array}{c}6[323,331,334,335, \\
338,341]\end{array}$ & - & - \\
\hline H. zebra $\$ ¥$ & Northern Australia [165] & - & - & - & - & - \\
\hline H. zosterae \$ & $\begin{array}{c}\text { Gulf of Mexico, E Florida, } \\
\text { Bahamas, Bermuda } \\
{[164,165,172,339]}\end{array}$ & $1[283]$ & - & $\begin{array}{l}10[42,76,186,311 \\
323,331,335-339]\end{array}$ & $2[172,339]$ & $1[376]$ \\
\hline
\end{tabular}


The use of dry seahorses from markets was continued in later genetic studies [34,282, $286,287,320,323-325]$, one of which was based on a single specimen originally identified as H. capensis [287]. Because this rare species is a South African endemic protected under CITES, its record from a foreign market triggered suspicions, and a subsequent molecular study has led to the conclusion that the specimen was misidentified [288]. This could not prevent a notice in a recent publication stating that this species is exported from Africa [178].

Molecular techniques may help to detect which species are represented in large shipments of dried seahorse, which are expected to be composed of multiple species mixes [258]. Another future application for molecular analyses could be the examination of gut contents of possible predators for the presence of seahorse DNA (as "environmental DNA" or eDNA). There appear to be very few reports on seahorse predators, such as crabs, cephalopods, fish, and sea turtles [248,383-385], while for the keeping of seahorses in mariculture and aquariums it may be useful to know more about their natural enemies.

Since 2003, various studies were aimed at the conservation genetics of rare species, starting with H. capensis [282,284]. Since 2013 [318], an increasing number of publications have presented the entire mitochondrial genome of Hippocampus species for identification purposes (Table 5), and many of these results were used in phylogeny reconstructions. So far, no studies were found in which barcoding was applied to the identification of seahorses in the aquarium trade. Thirteen apparently rare species with restricted distribution ranges in the Indo-Pacific have not been studied from a phylogenetic perspective: $H$. debelius and $H$. lichtensteinii in the Red Sea, $H$. tyro in the Seychelles, $H$. satomiae and $H$. waleananus in eastern Indonesia, $H$. planifroms in western Australia, $H$. paradoxus in southwestern Australia, $H$. tristis in southern Australia, H. zebra in northern Australia, H. dahlia in northern and eastern Australia, H. colemani and H. minotaur at Lord Howe Island (off southeastern Australia), and H. pusillus in New Caledonia (Table 5).

Most molecular seahorse studies involved phylogeny reconstructions, particularly those on species in the traditional medicine trade (Table 5). Molecular studies were also used to determine the taxonomic status of some Hippocampus species [32,168,316,319], including new ones [72,81-83]. They also found species that had been misidentified in local faunas [32]. For the conservation of seahorses, it is important to know which taxonomic names are valid and where species occur.

Phylogeographic studies tell us about how lineages within species populations are distributed (Table 5). In future studies, genetics can be applied to find out which seahorses and related species form unique phylogenetic lineages within the family Syngnathidae. This information, in combination with IUCN red list data, can be used to select evolutionary distinct taxa that need priority regarding research effort to support their conservation management, as previously done for corals and various other groups of organisms [386-388]. Meanwhile, it is very likely that new, cryptic species are going to be discovered in the coming years.

\section{Conclusions}

Most recent reports on the international trade in seahorses concern dead specimens, whereas live seahorses have received relatively little attention. This makes sense as live animals form a clear minority in the seahorse trade [389], but this does not mean that the market in live animals does not form a threat to the natural populations [30].

Nevertheless, in the international trade of marine ornamental fishes, seahorses form an important example by being the first species group for which trade is regulated under CITES. Because the popularity of these ornamental fishes is much related to their iconic appearance and reproduction mode [28,390], lessons learned from the seahorse trade may be useful for the protection of aquarium fishes that will enter future CITES listings. This will likely stimulate the cultivation of these other ornamental fish species and reduce the risk of overfishing, but it should not distract us from the need for the protection of their natural habitats. 
The diversity of seahorse species present and absent in the aquarium industry is the central theme of this study, and therefore, much emphasis is placed on the history of species discovery, ecology, and body size. Specimen identification remains a common and recurrent problem in this industry. An overview of genetic studies shows that many seahorse species have been subjected to molecular analyses and that rare species in particular are not well represented. Hopefully, in the future, similar studies will be applied to other species in the international aquarium trade.

Author Contributions: Both authors contributed to the conceptualization, methodology, analyses, writing - original draft preparation, writing - review and editing, and project administration. All authors have read and agreed to the published version of the manuscript.

Funding: This research received no external funding.

Acknowledgments: The authors are very grateful to Sarah Foster (Project Seahorse, University of British Columbia) and two anonymous reviewers for constructive comments on the manuscript and to Martine Maan (GELIFES, University of Groningen) for remarks on the MSc essay by the first author that formed the basis for the present paper. The editors and managers of WoRMS [66], FishBase [67], the IUCN Red List [68], and the CITES Trade Database [69] are acknowledged for keeping seahorse data up to date.

Conflicts of Interest: The authors declare no conflict of interest.

\section{References}

1. Wood, E. Collection of Coral Reef Fishes for Aquaria: Global Trade, Conservation Issues and Management Strategies; Marine Conservation Society: Ross-on-Wye, UK, 2001; p. 56.

2. Wabnitz, C.; Taylor, M.; Green, E.; Razak, T. From Ocean to Aquarium: The Global Trade in Marine Ornamental Species; UNEP-WCMC Biodiversity Series 17; UNEP-WCMC: Cambridge, UK, 2003; p. 64.

3. Rhyne, A.L.; Tlusty, M.F.; Schofield, P.J.; Kaufman, L.; Morris, J.A., Jr.; Bruckner, A.W. Revealing the appetite of the marine aquarium fish trade: The volume and biodiversity of fish imported into the United States. PLoS ONE 2012, 7, e35808. [CrossRef] [PubMed]

4. Leal, M.C.; Vaz, M.C.M.; Puga, J.; Rocha, R.J.M.; Brown, C.; Rosa, R.; Calado, R. Marine ornamental fish imports in the European Union: An economic perspective. Fish Fish. 2016, 17, 459-468. [CrossRef]

5. Biondo, M.V.; Burki, R.P. Monitoring the trade in marine ornamental fishes through the European trade control and expert system TRACES: Challenges and possibilities. Mar. Policy 2019, 108, 103620. [CrossRef]

6. Dee, L.E.; Karr, K.A.; Landesberg, C.J.; Thornhill, D.J. Assessing vulnerability of fish in the U.S. marine aquarium trade. Front. Mar. Sci. 2019, 5, 527. [CrossRef]

7. Biondo, M.V.; Burki, R.P. A systematic review of the ornamental fish trade with emphasis on coral reef fishes-An impossible task. Animals 2020, 10, 2014. [CrossRef] [PubMed]

8. Friedlander, A.M. Essential fish habitat and the effective design of marine reserves: Application for marine ornamental fishes. Aquar. Sci. Conserv. 2001, 3, 135-150. [CrossRef]

9. Zajicek, P.; Hardin, S.; Watson, C. A Florida marine ornamental pathway risk analysis. Rev. Fish. Sci. 2009, 17, 156-169. [CrossRef]

10. Cohen, F.P.A.; Valenti, W.C.; Calado, R. Traceability issues in the trade of marine ornamental species. Rev. Fish. Sci. 2013, 21, 98-111. [CrossRef]

11. Barber, C.V.; Pratt, V.R. Sullied Seas: Strategies for Combating Cyanide Fishing in Southeast Asia and Beyond; World Resources Institute: Washington, DC, USA, 1997.

12. Lecchini, D.; Polti, S.; Nakamura, Y.; Mosconi, P.; Tsuchiya, M.; Remoissenet, G.; Planes, S. New perspectives on aquarium fish trade. Fish. Sci. 2006, 72, 40-47. [CrossRef]

13. Shuman, C.S.; Hodgson, G.; Ambrose, R.F. Population impacts of collecting sea anemones and anemonefish for the marine aquarium trade in the Philippines. Coral Reefs 2005, 24, 564-573. [CrossRef]

14. Jones, A.M.; Gardner, S.; Sinclair, W. Losing 'Nemo': Bleaching and collection appear to reduce inshore populations of anemonefishes. J. Fish Biol. 2008, 73, 753-761. [CrossRef]

15. Morrisey, D.; Inglis, G.; Neil, K.; Bradley, A.; Fitridge, I. Characterization of the marine aquarium trade and management of associated marine pests in Australia, a country with stringent import biosecurity regulation. Environ. Conserv. 2011, 38, 89-100. [CrossRef]

16. Betancur, R.R.; Hines, A.; Acero, P.A.; Ortí, G.; Wilbur, A.E.; Freshwater, D.W.; Betancur, R.R.; Hines, A.; Ortí, G.; Wilbur, A.E.; et al. Reconstructing the lionfish invasion: Insights into Greater Caribbean biogeography. J. Biogeogr. 2011, 38, 1281-1293. [CrossRef]

17. Côté, I.M.; Green, S.J.; Hixon, M.A. Predatory fish invaders: Insights from Indo-Pacific lionfish in the western Atlantic and Caribbean. Biol. Conserv. 2013, 164, 50-61. [CrossRef] 
18. Padilla, D.K.; Williams, S.L. Beyond ballast water: Aquarium and ornamental trades as sources of invasive species in aquatic ecosystems. Front. Ecol. Environ. 2004, 2, 131-138. [CrossRef]

19. Ferreira, C.E.L.; Luiz, O.J.; Floeter, S.R.; Lucena, M.B.; Barbosa, M.C.; Rocha, C.R.; Rocha, L.A. First record of invasive lionfish (Pterois volitans) for the Brazilian coast. PLoS ONE 2015, 10, e0123002. [CrossRef]

20. Dimitriou, A.C.; Chartosia, N.; Hall-Spencer, J.M.; Kleitou, P.; Jimenez, C.; Antoniou, C.; Hadjioannou, L.; Kletou, D.; Sfenthourakis, S. Genetic data suggest multiple introductions of the lionfish (Pterois miles) into the Mediterranean sea. Diversity 2019, 11, 149. [CrossRef]

21. Bell, J.D.; Clua, E.; Hair, C.A.; Galzin, R.; Doherty, P.J. The capture and culture of post-larval fish and invertebrates for the marine ornamental trade. Rev. Fish. Sci. 2009, 17, 223-240. [CrossRef]

22. Foster, S.J.; Stanton, L.M.; Nellas, A.C.; Arias, M.M.; Vincent, A.C.J. The Catch and Trade of Seahorses in the Philippines Post-CITES. In Fisheries Centre Research Reports 27(2); University of British Columbia: Vancouver, BC, Canada, $2019 ;$; 45.

23. Stocks, A.P.; Foster, S.J.; Bat, N.K.; Ha, N.M.; Vincent, A.C.J. Local fishers' knowledge of target and incidental seahorse catch in southern Vietnam. Hum. Ecol. 2019, 47, 397-408. [CrossRef]

24. Ballesteros, L.V.; Matthews, J.L.; Hoeksema, B.W. Pollution and coral damage caused by derelict fishing gear on coral reefs around Koh Tao, Gulf of Thailand. Mar. Pollut. Bull. 2018, 135, 1107-1116. [CrossRef]

25. Olivier, K. World Trade in Ornamental Species. In Marine Ornamental Species: Collection, Culture and Conservation; Cato, J., Brown, B., Eds.; Iowa State Press: Ames, IA, USA, 2003; pp. 49-63.

26. Livengood, E.J.; Chapman, F.A. The Ornamental Fish Trade: An Introduction with Perspectives for Responsible Aquarium Fish Ownership, Publication FA124; Institute of Food and Agricultural Sciences, University of Florida: Gainesville, FL, USA, 2011 ; p. 7.

27. Hodgson, G. A global assessment of human effects on coral reefs. Mar. Pollut. Bull. 1999, 38, 345-355. [CrossRef]

28. Vincent, A.C.J.; Foster, S.J.; Koldewey, H.J. Conservation and management of seahorses and other Syngnathidae. J. Fish Biol. 2011, 78, 1681-1724. [CrossRef]

29. Foster, S.J.; Vincent, A.C.J. Life history and ecology of seahorses: Implications for conservation and management. J. Fish Biol. 2004, 65, 1-61. [CrossRef]

30. Lourie, S.A.; Foster, S.J.; Cooper, E.W.T.; Vincent, A.C.J. A Guide to the Identification of Seahorses; Project Seahorse; University of British Columbia: Vancouver, BC, Canada; TRAFFIC North America: Washington, DC, USA, 2004; p. 114.

31. Rosa, I.L.; Defavari, G.R.; Alves, R.R.N.; Oliveira, T.P.R. Seahorses in Traditional Medicines: A global Overview. In Animals in Traditional Folk Medicine; Metzler, J.B., Ed.; Springer: Berlin/Heidelberg, Germany, 2013; pp. 207-240.

32. Lourie, S.A.; Pritchard, J.C.; Casey, S.P.; Truong, S.K.; Hall, H.J.; Vincent, A.C.J. The taxonomy of Vietnam's exploited seahorses (family Syngnathidae). Biol. J. Linn. Soc. 1999, 66, 231-256. [CrossRef]

33. Foster, S.; Wiswedel, S.; Vincent, A. Opportunities and challenges for analysis of wildlife trade using CITES data-seahorses as a case study. Aquat. Conserv. Mar. Freshw. Ecosyst. 2014, 26, 154-172. [CrossRef]

34. Zeng, L.; Armani, A.; Wen, J.; Lin, H.; Xu, Y.; Fan, S.; Sun, Y.; Yang, C.; Chen, Z.; Chen, D.; et al. Molecular identification of seahorse and pipefish species sold as dried seafood in China: A market-based survey to highlight the actual needs for a proper trade. Food Control. 2019, 103, 175-181. [CrossRef]

35. Salin, K.R.; Yohannan, T.M.; Nair, C.M. Fisheries and trade of seahorses, Hippocampus spp., in Southern India. Fish. Manag. Ecol. 2005, 12, 269-273. [CrossRef]

36. Baum, J.K.; Meeuwig, J.J.; Vincent, A.C.J. Bycatch of seahorse (Hippocampus erectus) in a Gulf of Mexico shrimp trawl fishery. Fish. Bull. 2003, 101, 721-731.

37. Kuo, T.-C.; Laksanawimol, P.; Aylesworth, L.; Foster, S.J.; Vincent, A.C.J. Changes in the trade of bycatch species corresponding to CITES regulations: The case of dried seahorse trade in Thailand. Biodivers. Conserv. 2018, 27, 3447-3468. [CrossRef]

38. Aylesworth, L.; Phoonsawat, R.; Vincent, A.C.J. Effects of indiscriminate fisheries on a group of small data-poor species in Thailand. ICES J. Mar. Sci. 2017, 75, 642-652. [CrossRef]

39. Silveira, R.; Barcelos, B.T.; Oliveira, R.L.; Silva, J.S. Records of bycatch of Hippocampus patagonicus (Pisces: Syngnathidae) in commercial fishing in southern Brazil. Lat. Am. J. Aquat. Res. 2018, 46, 744-755. [CrossRef]

40. National Marine Fisheries Service. Status Review Report: Dwarf Seahorse (Hippocampus Zosterae); Office of Protected Resources, National Oceanic and Atmospheric Administration: Silver Spring, MD, USA, 2020; p. 84.

41. Vincent, A.C.; Meeuwig, J.J.; Pajaro, M.G.; Perante, N.C. Characterizing a small-scale, data-poor, artisanal fishery: Seahorses in the central Philippines. Fish. Res. 2007, 86, 207-215. [CrossRef]

42. Teske, P.R.; Beheregaray, L.B. Evolution of seahorses' upright posture was linked to Oligocene expansion of seagrass habitats. Biol. Lett. 2009, 5, 521-523. [CrossRef] [PubMed]

43. Oliver, M.P.; Burhans, R.; Simões, N.; Planas, M. Seahorses and Pipefish. In Marine Ornamental Species Aquaculture; Wiley-Blackwell: Hoboken, NJ, USA, 2017; pp. 299-326.

44. Teitelbaum, A.; Dubosc, J. Seahorses: Trade, aquaculture and their long-term outlook in New Caledonia. SPC Fish. Newsl. 2017, 152, 3233.

45. Kuiter, R.H. Seahorses, Pipefishes and Their Relatives: A Comprehensive Guide to Syngnathiformes; TMC Publishing: Chorleywood, UK, 2000; p. 240.

46. Kuiter, R.H. Seahorses and Their Relatives; Aquatic Photographics: Seaford, Australia, 2009; p. 333. 
47. Harasti, D. Declining seahorse populations linked to loss of essential marine habitats. Mar. Ecol. Prog. Ser. 2016, 546, 173-181. [CrossRef]

48. Vincent, A.C.J.; De Mitcheson, Y.J.S.; Fowler, S.L.; Lieberman, S.S. The role of CITES in the conservation of marine fishes subject to international trade. Fish Fish. 2014, 15, 563-592. [CrossRef]

49. Vincent, A.C.J.; Foster, S.J. Setting precedent in export regulations for marine fishes with seahorses. Fisheries 2017, 42, 40-43. [CrossRef]

50. Kuo, T.-C.; Vincent, A. Assessing the changes in international trade of marine fishes under CITES regulations-A case study of seahorses. Mar. Policy 2018, 88, 48-57. [CrossRef]

51. Koldewey, H.J.; Martin-Smith, K.M. A global review of seahorse aquaculture. Aquaculture 2010, 302, 131-152. [CrossRef]

52. Foster, S.J. Seahorses (Hippocampus spp.) and the CITES Review of Significant Trade; Fisheries Centre Research Reports 24(4); University of British Columbia: Vancouver, BC, Canada, 2016; p. 48.

53. Aylesworth, L.; Foster, S.J.; Vincent, A.C. Realities of offering advice to governments on CITES. Conserv. Biol. 2019, 34, 644-653. [CrossRef] [PubMed]

54. CITES. List of Parties to the Convention. 2020. Available online: https://www.cites.org/eng/disc/parties/index.php (accessed on 30 September 2020).

55. Job, S.; Do, H.; Meeuwig, J.; Hall, H. Culturing the oceanic seahorse, Hippocampus Kuda. Aquaculture 2002, 214, 333-341. [CrossRef]

56. Vincent, A.C.J. The International Trade in Seahorses; TRAFFIC International: Cambridge, UK, 1996; p. 163.

57. Olivotto, I.; Chemello, G.; Vargas, A.; Randazzo, B.; Piccinetti, C.C.; Carnevali, O. Marine ornamental species culture: From the past to "Finding Dory". Gen. Comp. Endocrinol. 2017, 245, 116-121. [CrossRef] [PubMed]

58. Dawes, J. International Experience in Ornamental Marine Species Management. Part 1: Perspectives. In Workshop: Management Strategies for the Marine Ornate Species of the Gulf of California; La Paz: Baja California Sur, Mexico, 1998; pp. 18-19.

59. Moe, M.A. Marine ornamentals: The industry and the hobby. Proc. Marine Ornam. Univ. Hawaii Sea Grant College Progr. 2001, 99, 53-63.

60. Moe, M.A. Culture of Marine Ornamentals: For Love, for Money, and for Science. In Marine Ornamental Species: Collection, Culture $\mathcal{E}$ Conservation; Cato, J., Brown, C., Eds.; Iowa State Press: Ames, IA, USA, 2003; pp. 11-28.

61. Moorhead, J.A.; Zeng, C. Development of captive breeding techniques for marine ornamental fish: A review. Rev. Fish. Sci. 2010, 18, 315-343. [CrossRef]

62. Palmtag, M.R. The Marine Ornamental Species Trade. In Marine Ornamental Species Aquaculture; Wiley-Blackwell: Hoboken, NJ, USA, 2017; pp. 3-14.

63. Woods, C.M.C. Factors affecting successful culture of the seahorse, Hippocampus abdominalis, Leeson, 1827. In Marine Ornamental Species. Collection, Culture E Conservation; Cato, J., Brown, C., Eds.; Iowa State Press: Ames, IA, USA, 2003; pp. $277-288$.

64. Payne, M.; Rippingale, R. Rearing West Australian seahorse, Hippocampus subelongatus, juveniles on copepod nauplii and enriched Artemia. Aquaculture 2000, 188, 353-361. [CrossRef]

65. Job, S.; Buu, D.; Vincent, A. Growth and survival of the tiger tail seahorse, Hippocampus comes. J. World Aquac. Soc. 2006, 37, 322-327. [CrossRef]

66. WoRMS Editorial Board. World Register of Marine Species. 2020. Available online: http://www.marinespecies.org/aphia.php? $\mathrm{p}=$ taxdetails\&id=126224 (accessed on 30 September 2020).

67. Froese, R.; Pauly, D.; FishBase. World Wide Web Electronic Publication. 2019. Available online: https://www.fishbase.org (accessed on 30 September 2020).

68. IUCN Red List search for Hippocampus. 2020. Available online: https:/ /www.iucnredlist.org/search?query=Hippocampus\& searchType $=$ species (accessed on 30 September 2020).

69. CITES Trade Database. 2020. Available online: https:// trade.cites.org (accessed on 30 September 2020).

70. Kuiter, R.H.; Tonozuka, T. Pictorial guide to Indonesian Reef Fishes. Part 1. Eels—Snappers, Muraenidae—Lutjanidae; Zoonetics: Melbourne, Australia, 2001; p. 866.

71. Curtis, J.M.R.; Vincent, A.C.J. Life history of an unusual marine fish: Survival, growth and movement patterns of Hippocampus guttulatus Cuvier 1829. J. Fish Biol. 2006, 68, 707-733. [CrossRef]

72. Han, S.-Y.; Kim, J.-K.; Kai, Y.; Senou, H. Seahorses of the Hippocampus coronatus complex: Taxonomic revision, and description of Hippocampus haema, a new species from Korea and Japan (Teleostei, Syngnathidae). ZooKeys 2017, 712, 113-139. [CrossRef]

73. Kuiter, R.H. Hippocampus tristis, a Lazarus species of seahorse (Teleostei: Syngnathidae) from Australia. J. Ocean Sci. Found. 2020, 35, 41-47. [CrossRef]

74. Kuiter, R.H. Revision of the Australian seahorses of the genus Hippocampus (Syngnathiformes: Syngnathidae) with descriptions of nine new species. Rec. Austr. Mus. 2001, 53, 293-340. [CrossRef]

75. Lourie, S.A.; Kuiter, R.H. Three new pygmy seahorse species from Indonesia (Teleostei: Syngnathidae: Hippocampus). Zootaxa 2008, 1963, 54-68. [CrossRef]

76. González, R.; Dinghi, P.; Corio, C.; Medina, A.; Maggioni, M.; Storero, L.; Gosztonyi, A. Genetic evidence and new morphometric data as essential tools to identify the Patagonian seahorse Hippocampus patagonicus (Pisces, Syngnathidae). J. Fish Biol. 2014, 84, 459-474. [CrossRef] [PubMed]

77. Fricke, R. Review of the pipefishes and seahorses (Teleostei: Syngnathidae) of New Caledonia, with descriptions of five new species. Stutt. Beitr. Naturkd. Ser. A 2004, 668, 1-66. 
78. Gomon, M.F.; Kuiter, R.H. Two new pygmy seahorses (Teleostei: Syngnathidae: Hippocampus) from the Indo-West Pacific. Aqua Int. J. Ichthyol. 2009, 15, 37-44.

79. Randall, J.E.; Lourie, S.A. Hippocampus tyro, a new seahorse (Gasterosteiformes: Syngnathidae) from the Seychelles. Smithiana Bull. 2009, 10, 19-21.

80. Short, G.; Smith, R.; Motomura, H.; Harasti, D.; Hamilton, H. Hippocampus japapigu, a new species of pygmy seahorse from Japan, with a redescription of $H$. pontohi (Teleostei, Syngnathidae). ZooKeys 2018, 779, 27-49. [CrossRef] [PubMed]

81. Foster, R.; Gomon, M.F. A new seahorse (Teleostei: Syngnathidae: Hippocampus) from south-western Australia. Zootaxa 2010, 2613, 61-68. [CrossRef]

82. Zhang, Y.-H.; Qin, G.; Wang, X.; Lin, Q. A new species of seahorse (Teleostei: Syngnathidae) from the South China Sea. Zootaxa 2016, 4170, 384-392. [CrossRef] [PubMed]

83. Short, G.; Claassens, L.; Smith, R.; De Brauwer, M.; Hamilton, H.; Stat, M.; Harasti, D. Hippocampus nalu, a new species of pygmy seahorse from South Africa, and the first record of a pygmy seahorse from the Indian Ocean (Teleostei, Syngnathidae). ZooKeys 2020, 934, 141-156. [CrossRef]

84. Gardner, T. The copepod/Artemia Tradeoff in the Captive Culture of Hippocampus erectus, a Vulnerable Species in Lower New York State. In Marine Ornamental Species. Collection, Culture \& Conservation; Cato, J., Brown, C., Eds.; Iowa State Press: Ames, IA, USA, 2003; pp. 297-303.

85. Payne, M.F. Rearing the Coral Seahorse, Hippocampus barbouri, on Live and Inert Prey. In Marine Ornamental Species. Collection, Culture E Conservation; Cato, J., Brown, C., Eds.; Iowa State Press: Ames, IA, USA, 2003; pp. 289-296.

86. Olivotto, I.; Planas, M.; Simões, N.; Holt, G.J.; Avella, M.A.; Calado, R. Advances in breeding and rearing marine ornamentals. J. World Aquac. Soc. 2011, 42, 135-166. [CrossRef]

87. Utter, F.; Epifanio, J. Marine aquaculture: Genetic potentialities and pitfalls. Rev. Fish Biol. Fish. 2002, 12, 59-77. [CrossRef]

88. Primavera, J.H. Global voices of science: Mangroves, fishponds, and the quest for sustainability. Science 2005, 310, 57-59. [CrossRef]

89. Pullin, R.; Sumaila, U.R. Aquaculture. In Fish for Life: Interactive Governance for Fisheries; Kooiman, J., Bavinck, M., Jentoft, S., Pullin, R., Eds.; Amsterdam University Press: Amsterdam, The Netherlands, 2005; pp. 93-108.

90. Weir, L.K.; Grant, J.W. Effects of aquaculture on wild fish populations: A synthesis of data. Environ. Rev. 2005, 13, 145-168. [CrossRef]

91. Tlusty, M. The benefits and risks of aquacultural production for the aquarium trade. Aquaculture 2002, 205, 203-219. [CrossRef]

92. Project Seahorse. IUCN SSC Seahorse, Pipefish and Seadragon Specialist Group. Available online: https://www.iucn-seahorse. org/iucn-global-assessments (accessed on 30 September 2020).

93. Bos, A.R.; Hoeksema, B.W. Cryptobenthic fishes and co-inhabiting shrimps associated with the mushroom coral Heliofungia actiniformis (Fungiidae) in the Davao Gulf, Philippines. Environ. Biol. Fishes 2014, 98, 1479-1489. [CrossRef]

94. Bos, A.R.; Hoeksema, B.W. Mushroom corals (Fungiidae) in the Davao Gulf, Philippines, with records of associated fish and other cryptofauna. Raffles Bull. Zool. 2017, 65, 198-206.

95. Brandl, S.J.; Goatley, C.H.R.; Bellwood, D.R.; Tornabene, L. The hidden half: Ecology and evolution of cryptobenthic fishes on coral reefs. Biol. Rev. 2018, 93, 1846-1873. [CrossRef]

96. De Brauwer, M.; Hobbs, J.A.; Ambo-Rappe, R.; Jompa, J.; Harvey, E.S.; Mcllwain, J.L. Biofluorescence as a survey tool for cryptic marine species. Conserv. Biol. 2018, 32, 706-715. [CrossRef]

97. De Brauwer, M.; Hobbs, J.-P.A.; Jompa, J. Widespread low abundance despite habitat availability elevates extinction risk in pygmy seahorses. Coral Reefs 2020, 39, 847-852. [CrossRef]

98. Lourie, S.A.; Randall, J.E. A new pygmy seahorse, Hippocampus denise (Teleostei: Syngnathidae), from the Indo-Pacific. Zool. Stud. 2003, 42, 284-291.

99. Nishikawa, J.; Fitzpatrick, R.; Reimer, J.D.; Beaman, R.J.; Yamamoto, H.; Lindsay, D.J. In situ observation of Denise's pygmy seahorse Hippocampus denise associated with a gorgonian coral Annella reticulata at Osprey Reef, Australia. Galaxea J. Coral Reef Stud. 2011, 13, 25-26. [CrossRef]

100. Van Der Meij, S.E.; Reijnen, B.T.; Van Ofwegen, L.P. Fish, fans and hydroids: Host species of pygmy seahorses. ZooKeys 2011, 103, 1-26. [CrossRef]

101. Foster, R.; Bridge, T.C.L.; Bongaerts, P. The first record of Hippocamus denise (Syngnathidae) from Australia. Aqua Int. J. Ichthyol. 2012, 18, 55-57.

102. Smith, R.E.; Grutter, A.S.; Tibbetts, I.R. Extreme habitat specialisation and population structure of two gorgonian-associated pygmy seahorses. Mar. Ecol. Prog. Ser. 2012, 444, 195-206. [CrossRef]

103. Shepherd, B.; Wandell, M.; Ross, R. Mating, birth, larval development and settlement of Bargibant's pygmy seahorse, Hippocampus bargibanti (Syngnathidae), in aquaria. AACL Bioflux 2017, 10, 1049-1063.

104. Gomon, M.F. A remarkable new pygmy seahorse (Syngnathidae: Hippocampus) from southeastern Australia, with a redescription of H. bargibanti Whitley from New Caledonia. Mem. Mus. Vic. 1997, 56, 245-253. [CrossRef]

105. Hoeksema, B.W. The hidden biodiversity of tropical coral reefs. Biodiversity 2017, 18, 8-12. [CrossRef]

106. Heard, J.; Chen, J.-P.; Wen, C.K.C. Citizen science yields first records of Hippocampus japapigu and Hippocampus denise (Syngnathidae) from Taiwan: A hotspot for pygmy seahorse diversity. ZooKeys 2019, 883, 83-90. [CrossRef] [PubMed] 
107. Smith, R.E.; Tibbetts, I.R. Mating and birth of Denise's pygmy seahorses (Hippocampus denise) observed in the wild. Coral Reefs 2008, 27, 617. [CrossRef]

108. Freret-Meurer, N.; Fernández, T.; Okada, N.; Vaccani, A.; Úrsula, R.D.J.U.S. Population dynamics of the endangered seahorse Hippocampus reidi Ginsburg, 1933 in a tropical rocky reef habitat. Anim. Biodivers. Conserv. 2018, 41, 345-456. [CrossRef]

109. Vincent, A.C. A role for daily greetings in maintaining seahorse pair bonds. Anim. Behav. 1995, 49, 258-260. [CrossRef]

110. Moreau, M.-A.; Vincent, A.C.J. Social structure and space use in a wild population of the Australian short-headed seahorse Hippocampus breviceps Peters, 1869. Mar. Freshw. Res. 2004, 55, 231-239. [CrossRef]

111. Bell, E.M.; Lockyear, J.F.; McPherson, J.M.; Marsden, A.D.; Vincent, A.C. First field studies of an endangered South African seahorse, Hippocampus capensis. Environ. Biol. Fishes 2003, 67, 35-46. [CrossRef]

112. Vaccani, A.C.; Freret-Meurer, N.V.; Bertoncini, Á.A.; Santos, L.N. Shining in the dark: First record of biofluorescence in the seahorse Hippocampus reidi. PLoS ONE 2019, 14, e0220561. [CrossRef]

113. Curtis, J.; Vincent, A. Distribution of sympatric seahorse species along a gradient of habitat complexity in a seagrass-dominated community. Mar. Ecol. Prog. Ser. 2005, 291, 81-91. [CrossRef]

114. Vincent, A.C.J.; Evans, K.L.; Marsden, A.D. Home range behaviour of the monogamous Australian seahorse, Hippocampus whitei. Environ. Biol. Fishes 2005, 72, 1-12. [CrossRef]

115. Teske, P.R.; Lockyear, J.F.; Hecht, T.; Kaiser, H. Does the endangered Knysna seahorse, Hippocampus capensis, have a preference for aquatic vegetation type, cover or height? Afr. Zool. 2007, 42, 23-30. [CrossRef]

116. Choi, Y.-U.; Rho, S.; Park, H.-S.; Kang, D.-H. Population characteristics of two seahorses, Hippocampus coronatus and Hippocampus mohnikei, around seagrass beds in the southern coastal waters of Korea. Ichthyol. Res. 2012, 59, 235-241. [CrossRef]

117. Aylesworth, L.; Lawson, J.M.; Laksanawimol, P.; Ferber, P.; Loh, T.-L. New records of the Japanese seahorse Hippocampus mohnikei in Southeast Asia lead to updates in range, habitat and threats. J. Fish Biol. 2016, 88, 1620-1630. [CrossRef]

118. Pinault, M.; Wickel, J.; Nicet, J.-B.; Chenoz, M.; de Montgolfier, B.; Fricke, R. First record of the near threatened native seahorse Hippocampus reidi (Teleostei: Syngnathidae) in an ecosystem dominated by the invasive seagrass Halophila stipulacea in the Caribbean Sea. Cybium 2018, 42, 393-396. [CrossRef]

119. Goffredo, S.; Piccinetti, C.; Zaccanti, F. Volunteers in marine conservation monitoring: A study of the distribution of seahorses carried out in collaboration with recreational scuba divers. Conserv. Biol. 2004, 18, 1492-1503. [CrossRef]

120. Dias, T.L.; Rosa, I.L. Habitat preferences of a seahorse species, Hippocampus reidi (Teleostei: Syngnathidae) in Brazil. Aqua Int. J. Ichthyol. 2003, 6, 165-176.

121. Rosa, I.L.; Oliveira, T.P.R.; Castro, A.L.C.; Moraes, L.E.D.S.; Xavier, J.H.A.; Nottingham, M.C.; Dias, T.L.P.; Bruto-Costa, L.V.; Araújo, M.E.; Birolo, A.B.; et al. Population characteristics, space use and habitat associations of the seahorse Hippocampus reidi (Teleostei: Syngnathidae). Neotrop. Ichthyol. 2007, 5, 405-414. [CrossRef]

122. Aylesworth, L.A.; Xavier, J.H.; Oliveira, T.P.R.; Tenorio, G.D.; Diniz, A.F.; Rosa, I.L. Regional-scale patterns of habitat preference for the seahorse Hippocampus reidi in the tropical estuarine environment. Aquat. Ecol. 2015, 49, 499-512. [CrossRef]

123. Harasti, D.; Martin-Smith, K.; Gladstone, W. Ontogenetic and sex-based differences in habitat preferences and site fidelity of White's seahorse Hippocampus whitei. J. Fish Biol. 2014, 85, 1413-1428. [CrossRef] [PubMed]

124. Qin, G.; Zhang, Y.; Huang, L.; Lin, Q. Effects of water current on swimming performance, ventilation frequency, and feeding behavior of young seahorses (Hippocampus erectus). J. Exp. Mar. Biol. Ecol. 2014, 461, 337-343. [CrossRef]

125. Simpson, M.; Morris, R.L.; Harasti, D.; Coleman, R.A. Swimming nets have positive effects on populations of the endangered White's seahorse Hippocampus whitei. Aquat. Conserv. Mar. Freshw. Ecosyst. 2021, 31, 60-73. [CrossRef]

126. Correia, M.; Palma, J.; Koldewey, H.; Andrade, J.P. Can artificial holdfast units work as a habitat restoration tool for long-snouted seahorse (Hippocampus guttulatus Cuvier)? J. Exp. Mar. Biol. Ecol. 2013, 448, 258-264. [CrossRef]

127. Correia, M.; Koldewey, H.; Andrade, J.P.; Palma, J. Effects of artificial holdfast units on seahorse density in the Ria Formosa lagoon, Portugal. J. Exp. Mar. Biol. Ecol. 2015, 471, 1-7. [CrossRef]

128. Claassens, L. An artificial water body provides habitat for an endangered estuarine seahorse species. Estuar. Coast. Shelf Sci. 2016, 180, 1-10. [CrossRef]

129. Claassens, L.; Hodgson, A.N. Monthly population density and structure patterns of an endangered seahorse Hippocampus capensis: A comparison between natural and artificial habitats. J. Fish Biol. 2018, 92, 2000-2015. [CrossRef] [PubMed]

130. Claassens, L.; Booth, A.J.; Hodgson, A.N. An endangered seahorse selectively chooses an artificial structure. Environ. Biol. Fishes 2018, 101, 723-733. [CrossRef]

131. Simpson, M.; Morris, R.L.; Harasti, D.; Coleman, R.A. The endangered White's seahorse Hippocampus whitei chooses artificial over natural habitats. J. Fish Biol. 2019, 95, 555-561. [CrossRef] [PubMed]

132. Simpson, M.; Coleman, R.A.; Morris, R.L.; Harasti, D. Seahorse hotels: Use of artificial habitats to support populations of the endangered White's seahorse Hippocampus whitei. Mar. Environ. Res. 2020, 157, 104861. [CrossRef]

133. Evanson, M.; Foster, S.J.; Wisedel, S.; Vincent, A.C.J. Tracking the International Trade of Seahorses (Hippocampus Species); Fisheries Centre Research Reports 19; University of British Columbia: Vancouver, BC, Canada, 2011; p. 94.

134. Zhang, Y.Y.; Ryu, B.-M.; Qian, Z.-J. A review-Biology, aquaculture and medical use of seahorse, Hippocampus spp. Annu. Res. Rev. Biol. 2017, 14, 1-12. [CrossRef]

135. Rosa, I.L.; Oliveira, T.P.R.; Osório, F.M.; Moraes, L.E.; Castro, A.L.C.; Barros, G.M.L.; Alves, R.R.N. Fisheries and trade of seahorses in Brazil: Historical perspective, current trends, and future directions. Biodivers. Conserv. 2011, 20, 1951-1971. [CrossRef] 
136. Sanaye, S.V.; Khandeparker, R.; Rayadurga, A.S.; Shivaramu, M.S.; Kankonkar, H.; Narvekar, J.; Gauthankar, M. Morphological and molecular evidence for first records and range extension of the Japanese seahorse, Hippocampus mohnikei (Bleeker, 1853) in a bay-estuarine system of Goa, central west coast of India. PLoS ONE 2020, 15, e0220420. [CrossRef]

137. Qin, G.; Zhang, Y.; Ho, A.L.F.C.; Zhang, Y.; Lin, Q. Seasonal distribution and reproductive strategy of seahorses. ICES J. Mar. Sci. 2017, 74, 2170-2179. [CrossRef]

138. Han, S.-Y.; Kim, J.-K.; Tashiro, F.; Kai, Y.; Yoo, J.-T. Relative importance of ocean currents and fronts in population structures of marine fish: A lesson from the cryptic lineages of the Hippocampus mohnikei complex. Mar. Biodivers. 2017, 49, 263-275. [CrossRef]

139. Lourie, S.A.; Vincent, A.C.J. A marine fish follows Wallace's line: The phylogeography of the three-spot seahorse (Hippocampus trimaculatus, Syngnathidae, Teleostei) in Southeast Asia. J. Biogeogr. 2004, 31, 1975-1985. [CrossRef]

140. Meeuwig, J.J.; Hoang, D.H.; Ky, T.S.; Job, S.D.; Vincent, A.C. Quantifying non-target seahorse fisheries in central Vietnam. Fish. Res. 2006, 81, 149-157. [CrossRef]

141. Murugan, A.; Dhanya, S.; Sarcar, A.B.; Naganathan, V.; Rajagopal, S.; Balasubramanian, T. Fishery biology, demography of the three-spotted seahorse, Hippocampus trimaculatus inhabiting Gulf of Mannar region, southeast coast of India. Indian J. Geo-Mar. Sci. 2011, 40, 411-423.

142. Laksanawimol, P.; Petpiroon, S.; Damrongphol, P. Trade of seahorses, Hippocampus spp. (Actinopterygii: Syngnathiformes: Syngnathidae), on the east coast of the gulf of Thailand. Acta Ichthyol. Piscat. 2013, 43, 229-235. [CrossRef]

143. Ismail, M.S.; Harun, M.F.; Yap, C.K. Captive breeding, rearing and closing of reproductive cycle of the three spot seahorse, Hippocampus trimaculatus (Leach, 1814) PDF. Acad. J. Life Sci. 2020, 6, 27-33. [CrossRef]

144. Martin-Smith, K.M.; Vincent, A.C.J. Exploitation and trade of Australian seahorses, pipehorses, sea dragons and pipefishes (Family Syngnathidae). Oryx 2006, 40, 141-151. [CrossRef]

145. Parsons, E.C. Why IUCN should replace "Data Deficient" conservation status with a precautionary "Assume Threatened" status-A cetacean case study. Front. Mar. Sci. 2016, 3, 193. [CrossRef]

146. Martin-Smith, K.M.; Samoilys, M.A.; Meeuwig, J.J.; Vincent, A.C. Collaborative development of management options for an artisanal fishery for seahorses in the central Philippines. Ocean Coast. Manag. 2004, 47, 165-193. [CrossRef]

147. Bruckner, A.W.; Field, J.D.; Daves, N. (Eds.) The Proceedings of the International Workshop on CITES Implementation for Seahorse Conservation and Trade. NOAA Technical; Memorandum NMFS-OPR-36: Silver Spring, MD, USA, 2005; p. 171.

148. Foster, S.J.; Vincent, A.C.J. Enhancing sustainability of the international trade in seahorses with a single minimum size limit. Conserv. Biol. 2005, 19, 1044-1050. [CrossRef]

149. Carlson, J.K.; Horn, C.; Smith, K.L.; Bethea, D.M. Population viability analysis of the dwarf seahorse, Hippocampus zosterae, in Florida. NOAA Techn. Mem. 2019, NMFSSEFSC-SEFSC-739, 1-37. [CrossRef]

150. Masonjones, H.D.; Rose, E.; Masonjones, M.C. Techniques used to increase recapture rates of dwarf seahorses (Hippocampus zosterae) in Tampa Bay: Implications for population estimates and movement patterns. Gulf Caribb. Res. 2019, 30, 10-19. [CrossRef]

151. Giwojna, P. A Step-by-Step Book about Seahorses; T.F.H. Publications: Neptune City, NJ, USA, 1990; p. 64.

152. Garrick-Maidment, N. Seahorses: Conservation and Care; T.F.H. Kingdom Books: London, UK, 1997; p. 48.

153. Indiviglio, F. Seahorses. A Complete Pet Owner's Manual; B.E.S. Publishing: Hauppauge, NY, USA, $2001 ;$ p. 96.

154. Eldington, E. Seahorses as Pets. Seahorse Complete Owner's Manual. Seahorse Care, Health, Tank, Costs and Feeding; Imb Publishing: San Bernardino, CA, USA, 2015; p. 132.

155. Horsnby, T. So You Want to Keep Seahorses; CreateSpace Independent Publishing Platform: Charleston, SC, USA, 2016 ; p. 52.

156. French, M. Seahorses for Beginners, 2nd ed.; CreateSpace Independent Publishing Platform: Charleston, CA, USA, 2017 ; p. 165.

157. Abbott, A.W. The Complete Guide to Dwarf Seahorses in the Aquarium; T.F.H. Publications: Neptune City, NJ, USA, $2003 ;$ p. 144.

158. Horsnby, T. So You Want to Keep Dwarf Seahorses; CreateSpace Independent Publishing Platform: Charleston, CA, USA, 2016; p. 54.

159. French, M. Dwarf Seahorses for Beginners; CreateSpace Independent Publishing Platform: Charleston, CA, USA, $2019 ;$ p. 66.

160. Koldewey, H. (Ed.) Syngnathid Husbandry in Public Aquariums; Manual; Project Seahorse: Vancouver, BC, Canada; Zoological Society of London: London, UK, 2005; p. 137.

161. De Brauwer, M.; Gordon, L.M.; Shalders, T.C.; Saunders, B.J.; Archer, M.; Harvey, E.S.; Collin, S.P.; Partridge, J.C.; McIlwain, J.L. Behavioural and pathomorphological impacts of flash photography on benthic fishes. Sci. Rep. 2019, 9, 1-14. [CrossRef] [PubMed]

162. Giglio, V.J.; Ternes, M.L.F.; Kassuga, A.D.; Ferreira, C.E.L. Scuba diving and sedentary fish watching: Effects of photographer approach on seahorse behavior. J. Ecotourism 2018, 18, 142-151. [CrossRef]

163. Scales, H. Advances in the ecology, biogeography and conservation of seahorses (genus Hippocampus). Prog. Phys. Geogr. Earth Environ. 2010, 34, 443-458. [CrossRef]

164. Rose, E.; Simmonds, M.; Hayashida-Boyles, A.L.; Masonjones, H.D. Seasonal and spatial variation in the reproductive biology of the dwarf seahorse Hippocampus zosterae. J. Fish Biol. 2019, 95, 357-366. [CrossRef]

165. Lourie, S.A.; Pollom, R.A.; Foster, S.J. A global revision of the seahorses Hippocampus rafinesque 1810 (Actinopterygii: Syngnathiformes): Taxonomy and biogeography with recommendations for further research. Zootaxa 2016, 4146, 1-66. [CrossRef] [PubMed]

166. Subburaman, S.; Murugan, A.; Goutham, S.; Kaul, R.; Jothi, P.V.R.P.; Balasubramanian, T. First distributional record of the giraffe seahorse, Hippocampus camelopardalis Bianconi 1854 (Family: Syngnathidae) from Gulf of Kachchh waters, North west coast. Indian J. Geo-Mar. Sci. 2014, 43, 408-411. 
167. Kim, S.Y.; Kweon, S.M.; Choi, S.H. First record of Hippocampus sindonis (Syngnathiformes: Syngnathidae) from Korea. Korean J. Ichthyol. 2013, 25, 41-44.

168. Szabo, Z.; Kimokeo, B.K.; Toonen, R.J.; Randall, J.E. On the status of the Hawaiian seahorses Hippocampus hilonis, H. histrix and H. fisheri (Syngnathidae). Mar. Biol. Res. 2011, 7, 701-709. [CrossRef]

169. Brittain, K. Fishers' seahorse, Hippocampus fisheri. In Syngnathid Husbandry in Public Aquariums; Manual; Koldewey, H., Ed.; Project Seahorse: Vancouver, BC, Canada; Zoological Society of London: London, UK, 2005; pp. 62-63.

170. Vincent, A.C.J.; Koldewey, H.J. An uncertain future for seahorse aquaculture in conservation and economic contexts. In Proceedings of the Regional Technical Consultation on Stock Enhancement for Threatened Species of International Concern, Iloilo City, Philippines, 13-15 July 2005; Primavera, J.H., Quinitio, E.T., Eguia, M.R.R., Eds.; Aquaculture Department, Southeast Asian Fisheries Development Center: Tigbauan, Philippines, 2006; pp. 71-84.

171. Alford, K.; Grist, C. Dwarf Seahorse, Hippocampus zosterae. In Syngnathid Husbandry in Public Aquariums; Manual; Koldewey, H., Ed.; Project Seahorse: Vancouver, BC, Canada; Zoological Society of London: London, UK, 2005; pp. 88-90.

172. Fedrizzi, N.; Stiassny, M.L.J.; Boehm, J.T.; Dougherty, E.R.; Amato, G.; Mendez, M. Population genetic structure of the dwarf seahorse (Hippocampus zosterae) in Florida. PLoS ONE 2015, 10, e0132308. [CrossRef]

173. Chen, L.; Wang, X.; Huang, B. The genus Hippocampus-A review on traditional medicinal uses, chemical constituents and pharmacological properties. J. Ethnopharmacol. 2015, 162, 104-111. [CrossRef]

174. Kumaravel, K.; Ravichandran, S.; Balasubramanian, T.; Sonneschein, L. Seahorses-A source of traditional medicine. Nat. Prod. Res. 2012, 26, 2330-2334. [CrossRef]

175. Louw, S.; Bürgener, M. Seahorse trade dynamics from Africa to Asia. TRAFFIC Bull. 2020, 32, 37-44.

176. Nijman, V. An overview of international wildlife trade from Southeast Asia. Biodivers. Conserv. 2009, 19, 1101-1114. [CrossRef]

177. Foster, S.J.; Kuo, T.-C.; Wan, A.K.Y.; Vincent, A.C. Global seahorse trade defies export bans under CITES action and national legislation. Mar. Policy 2019, 103, 33-41. [CrossRef]

178. Lam, J.T.; Koldewey, H.J.; Yasue, M.; Vincent, A.C. Comparing interview and trade data in assessing changes in the seahorse Hippocampus spp. trade following CITES listing. Oryx 2014, 50, 36-46. [CrossRef]

179. Wright, K.A.; Woods, C.M.C.; Gray, B.E.; Lokman, P.M. Recovery from acute, chronic and transport stress in the pot-bellied seahorse Hippocampus abdominalis. J. Fish Biol. 2007, 70, 1447-1457. [CrossRef]

180. Cohen, F.P.; Planas, M.; Valenti, W.C.; Lillebø, A.; Calado, R. Optimizing packing of live seahorses for shipping. Aquaculture 2018, 482, 57-64. [CrossRef]

181. Cohen, F.P.A.; Valenti, W.C.; Planas, M.; Calado, R. Seahorse aquaculture, biology and conservation: Knowledge gaps and research opportunities. Rev. Fish. Sci. Aquac. 2016, 25, 100-111. [CrossRef]

182. Fioravanti, M.L.; Florio, D. Common diseases in marine ornamental fishes. Marine Ornam. Species Aquac. 2017, 347-380.

183. Dzyuba, B.; Van Look, K.J.W.; Cliffe, A.; Koldewey, H.J.; Holt, W.V. Effect of parental age and associated size on fecundity, growth and survival in the yellow seahorse Hippocampus kuda. J. Exp. Biol. 2006, 209, 3055-3061. [CrossRef]

184. Kawaguchi, M.; Okubo, R.; Harada, A.; Miyasaka, K.; Takada, K.; Hiroi, J.; Yasumasu, S. Morphology of brood pouch formation in the pot-bellied seahorse Hippocampus abdominalis. Zool. Lett. 2017, 3, 19. [CrossRef]

185. Stölting, K.N.; Wilson, A.B. Male pregnancy in seahorses and pipefish: Beyond the mammalian model. BioEssays 2007, $29,884-896$. [CrossRef]

186. Wilson, A.B.; Vincent, A.; Ahnesjö, I.; Meyer, A. Male pregnancy in seahorses and pipefishes (Family Syngnathidae): Rapid diversification of paternal brood pouch morphology inferred from a molecular phylogeny. J. Hered. 2001, 92, 159-166. [CrossRef] [PubMed]

187. Whittington, C.M.; Friesen, C.R. The evolution and physiology of male pregnancy in syngnathid fishes. Biol. Rev. 2020, 95, 1252-1272. [CrossRef]

188. Planas, M.; Quintas, P.; Chamorro, A.; Silva, C.N.S.; Oliver, M.P.; Planas, M. Female maturation, egg characteristics and fatty acids profile in the seahorse Hippocampus guttulatus. Anim. Reprod. Sci. 2010, 122, 66-73. [CrossRef] [PubMed]

189. Planas, M.; Quintas, P.; Chamorro, A.; Oliver, M.P. Maturation of Hippocampus guttulatus and Hippocampus hippocampus females by manipulation of temperature and photoperiod regimes. Aquaculture 2013, 388-391, 147-152. [CrossRef]

190. Teixeira, R.L.; Musick, J.A. Reproduction and food habits of the lined seahorse, Hippocampus erectus (Teleostei: Syngnathidae) of Chesapeake bay, Virginia. Braz. J. Biol. 2001, 61, 79-90. [CrossRef]

191. Woods, C.M.C. Natural diet of the seahorse Hippocampus abdominalis. N. Z. J. Mar. Freshw. Res. 2002, 36, 655-660. [CrossRef]

192. Kitsos, M.-S.; Tzomos, T.; Anagnostopoulou, L.; Koukouras, A. Diet composition of the seahorses, Hippocampus guttulatus Cuvier, 1829 and Hippocampus hippocampus (L., 1758) (Teleostei, Syngnathidae) in the Aegean Sea. J. Fish Biol. 2008, 72, $1259-1267$. [CrossRef]

193. Storero, L.P.; González, R.A. Prey selectivity and trophic behavior of the patagonian seahorse, Hippocampus patagonicus, in captivity. J. World Aquac. Soc. 2009, 40, 394-401. [CrossRef]

194. Gurkan, S.; Taskavak, E.; Sever, T.M.; Akalin, S. Gut contents of two European seahorses Hippocampus hippocampus and Hippocampus guttulatus in the Aegean Sea, Coasts of Turkey. Pak. J. Zool. 2011, 43, 1197-1201.

195. Valladares, S.; Soto, D.X.; Planas, M. Dietary composition of endangered seahorses determined by stable isotope analysis. Mar. Freshw. Res. 2017, 68, 831. [CrossRef] 
196. Nenciu, M.I.; Harcota, G.E.; Totoiu, A.; Bisinicu, E.; Filimon, A.; Nita, V.N. Prey preference of the long-snouted seahorse (Hippocampus guttulatus Cuvier, 1829) at the Romanian Black Sea coast. Sci. Pap. Ser. D. Anim. Sci. 2018, 61, $348-355$.

197. Castro, A.L.D.C.; Diniz, A.D.F.; Martins, I.Z.; Vendel, A.L.; De Oliveira, T.P.R.; Rosa, I.M.D.L. Assessing diet composition of seahorses in the wild using a non-destructive method: Hippocampus reidi (Teleostei: Syngnathidae) as a study-case. Neotrop. Ichthyol. 2008, 6, 637-644. [CrossRef]

198. Francesca, A.; Corriero, G.; Mirto, S.; Pierri, C.; Lazic, T.; Gristina, M. Trophic flexibility and prey selection of the wild long-snouted seahorse Hippocampus guttulatus Cuvier, 1829 in three coastal habitats. Estuar. Coast. Shelf Sci. 2019, 224, 1-10. [CrossRef]

199. Bergert, B.A.; Wainwright, P.C. Morphology and kinematics of prey capture in the syngnathid fishes Hippocampus erectus and Syngnathus floridae. Mar. Biol. 1997, 127, 563-570. [CrossRef]

200. Roos, G.; Van Wassenbergh, S.; Herrel, A.; Aerts, P.; Tresguerres, M.; Katoh, F.; Fenton, H.; Jasinska, E.; Goss, G.G. Kinematics of suction feeding in the seahorse Hippocampus reidi. J. Exp. Biol. 2009, 212, 3490-3498. [CrossRef]

201. Roos, G.; Van Wassenbergh, S.; Herrel, A.; Adriaens, D.; Aerts, P. Snout allometry in seahorses: Insights on optimisation of pivot feeding performance during ontogeny. J. Exp. Biol. 2010, 213, 2184-2193. [CrossRef]

202. Roos, G.; Van Wassenbergh, S.; Aerts, P.; Herrel, A.; Adriaens, D. Effects of snout dimensions on the hydrodynamics of suction feeding in juvenile and adult seahorses. J. Theor. Biol. 2011, 269, 307-317. [CrossRef]

203. Gemmell, B.J.; Sheng, J.; Buskey, E.J. Morphology of seahorse head hydrodynamically aids in capture of evasive prey. Nat. Commun. 2013, 4, 2840. [CrossRef]

204. Blanco, A.; Planas, M. Mouth growth and prey selection in juveniles of the European long-snouted seahorse, Hippocampus guttulatus. J. World Aquac. Soc. 2015, 46, 596-607. [CrossRef]

205. Manning, C.G.; Foster, S.J.; Vincent, A.C.J. A review of the diets and feeding behaviours of a family of biologically diverse marine fishes (Family Syngnathidae). Rev. Fish Biol. Fish. 2019, 29, 197-221. [CrossRef]

206. Olivotto, I.; Avella, M.; Sampaolesi, G.; Piccinetti, C.; Ruiz, P.N.; Carnevali, O. Breeding and rearing the longsnout seahorse Hippocampus reidi: Rearing and feeding studies. Aquaculture 2008, 283, 92-96. [CrossRef]

207. Hora, M.D.S.C.D.; Joyeux, J.-C. Closing the reproductive cycle: Growth of the seahorse Hippocampus reidi (Teleostei, Syngnathidae) from birth to adulthood under experimental conditions. Aquaculture 2009, 292, 37-41. [CrossRef]

208. Murugan, A.; Dhanya, S.; Sreepada, R.; Rajagopal, S.; Balasubramanian, T. Breeding and mass-scale rearing of three spotted seahorse, Hippocampus trimaculatus Leach under captive conditions. Aquaculture 2009, 290, 87-96. [CrossRef]

209. Planas, M.; Olivotto, I.; González, M.J.; Laurà, R.; Zarantoniello, M. A Multidisciplinary experimental study on the effects of breeders diet on newborn seahorses (Hippocampus guttulatus). Front. Mar. Sci. 2020, 7, 638. [CrossRef]

210. Planas, M. Carry-over effects of pre-breeding diets on seahorse (Hippocampus reidi) reproductive success. Aquaculture 2021, 533, 736148. [CrossRef]

211. Qin, G.; Lin, Q.; Gu, N.; Lin, J.; Huang, L. Effect of broodstock origin, background and substrate color on skin coloration of three-spotted seahorses Hippocampus trimaculatus Leach, 1814. J. Exp. Mar. Biol. Ecol. 2012, 416-417, 129-134. [CrossRef]

212. Segade, A.; Robaina, L.; Romero, J.G.; Domínguez, L.M.; Otero-Ferrer, F. Effects of the diet on seahorse (Hippocampus hippocampus) growth, body colour and biochemical composition. Aquac. Nutr. 2014, 21, 807-813. [CrossRef]

213. Fonseca, T.; David, F.S.; Ribeiro, F.A.S.; Wainberg, A.A.; Valenti, W.C. Technical and economic feasibility of integrating seahorse culture in shrimp/oyster farms. Aquac. Res. 2015, 48, 655-664. [CrossRef]

214. Adams, M.B.; Powell, M.D.; Purser, G.J. Effect of acute and chronic ammonia and nitrite exposure on oxygen consumption and growth of juvenile big bellied seahorse. J. Fish Biol. 2001, 58, 848-860. [CrossRef]

215. Chang, M.; Southgate, P.C. Effects of varying dietary fatty acid composition on growth and survival of seahorse, Hippocampus sp., juveniles. Aquar. Sci. Conserv. 2001, 3, 205-214. [CrossRef]

216. Project Seahorse. Seahorse Aquaculture. Position Statements. 20 April 2009. Available online: https://www.projectseahorse.org/ conservation-tools /2015/9/23/seahorse-aquaculture (accessed on 28 September 2020).

217. Li, H.; Sun, H.; Bai, X.; Lin, Q.; Liu, X.; Wang, Y.; Wang, L.; Yan, D. HC2 of Pseudomonas sp. Induced enteritis in Hippocampus japonicus. Aquac. Res. 2014, 47, 2027-2030. [CrossRef]

218. Xie, J.; Bu, L.; Jin, S.; Wang, X.; Zhao, Q.; Zhou, S.; Xu, Y. Outbreak of vibriosis caused by Vibrio harveyi and Vibrio alginolyticus in farmed seahorse Hippocampus kuda in China. Aquaculture 2020, 523, 735168. [CrossRef]

219. Alcaide, E.; Gil-Sanz, C.; Sanjuan, E.; Esteve, D.; Amaro, C.; Silveira, L.; Gil-Sanz, C. Vibrio harveyi causes disease in seahorse, Hippocampus sp. J. Fish Dis. 2001, 24, 311-313. [CrossRef]

220. Jiang, F.; Yang, N.; Huang, H.; Feng, H.; Li, Y.; Han, B. Short communication: Recovery of Vibrio vulnificus from head ulceration in seahorse (Hippocampus kuda). Aquac. Int. 2019, 28, 653-660. [CrossRef]

221. Lin, T.; Zhang, D.; Liu, X.; Xiao, D. Variations of immune parameters in the lined seahorse Hippocampus erectus after infection with enteritis pathogen of Vibrio parahaemolyticus. Fish Shellfish Immunol. 2016, 50, 247-254. [CrossRef]

222. Shao, P.; Yong, P.; Wang, X.; Xie, S.; Fan, Y.; Zang, L.; Cui, L.; Sun, J. Isolation, identification, and histopathological analysis of Vibrio tubiashii from lined seahorse Hippocampus erectus. Dis. Aquat. Org. 2019, 133, 195-205. [CrossRef] [PubMed]

223. Wang, R.; Pan, X.; Xu, Y. Altered intestinal microbiota composition associated with enteritis in yellow seahorses Hippocampus kuda (Bleeker, 1852). Curr. Microbiol. 2020, 77, 730-737. [CrossRef] [PubMed]

224. Qin, G.; Wang, X.; Tan, S.; Lin, Q. A bacterial infection by Vibrio harveyi causing heavy reduction of cultured lined seahorse Hippocampus erectus. J. Fish Dis. 2016, 40, 601-605. [CrossRef] [PubMed] 
225. Qin, G.; Zhang, Y.; Zhang, B.; Wang, X.; Yin, J.; Lin, Q. Seahorse TLR5 gene responses to Vibrio vulnificus infection, which in combination with scuticociliates causes heavy reductions in seahorse aquaculture. J. Fish Dis. 2018, 41, 1933-1936. [CrossRef]

226. Planas, M.; Chamorro, A.; Quintas, P.; Vilar, A. Establishment and maintenance of threatened long-snouted seahorse, Hippocampus guttulatus, broodstock in captivity. Aquaculture 2008, 283, 19-28. [CrossRef]

227. Palma, J.; Bureau, D.P.; Andrade, J.P. The effect of diet on ontogenic development of the digestive tract in juvenile reared long snout seahorse Hippocampus guttulatus. Fish Physiol. Biochem. 2013, 40, 739-750. [CrossRef]

228. Tanu; Deobagkar, D.D.; Khandeparker, R.; Sreepada, R.A.; Sanaye, S.V.; Pawar, H.B. A study on bacteria associated with the intestinal tract of farmed yellow seahorse, Hippocampus kuda (Bleeker, 1852): Characterization and extracellular enzymes. Aquac. Res. 2012, 43, 386-394. [CrossRef]

229. Li, F.; Wang, K.; Luo, W.; Huang, L.; Lin, Q. Comparison of the intestinal bacterial flora in healthy and intestinal-diseased seahorses Hippocampus trimaculatus, Hippocampus erectus, and Hippocampus spinosissimus. J. World Aquac. Soc. 2015, 46, 263-272. [CrossRef]

230. Wang, X.; Zhang, Y.; Qin, G.; Luo, W.; Lin, Q. A novel pathogenic bacteria (Vibrio fortis) causing enteritis in cultured seahorses, Hippocampus erectus Perry, 1810. J. Fish Dis. 2015, 39, 765-769. [CrossRef] [PubMed]

231. Williams, S.L.; Janetski, N.; Abbott, J.; Blankenhorn, S.; Cheng, B.; Crafton, R.E.; Hameed, S.O.; Rapi, S.; Trockel, D. Ornamental marine species culture in the coral triangle: Seahorse demonstration project in the Spermonde Islands, Sulawesi, Indonesia. Environ. Manag. 2014, 54, 1342-1355. [CrossRef] [PubMed]

232. Foster, S.J.; Aylesworth, L.; Do, H.H.; Bat, N.K.; Vincent, A.C.J. Seahorse Exploitation and Trade in Vietnam; Fisheries Centre Research Reports 25(2); University of British Columbia: Vancouver, BC, Canada, 2017; p. 53.

233. Hettiarachchi, H.A.S.U.; Edirisinghe, U. Captive breeding of Hippocampus reidi Ginsburg, 1933 (Longsnout Seahorse) in Sri Lanka under artificial conditions. Trop. Agric. Res. 2017, 29, 77. [CrossRef]

234. Ferrol-Schulte, D.; Wolff, M.; Ferse, S.; Glaser, M. Sustainable livelihoods approach in tropical coastal and marine social-ecological systems: A review. Mar. Policy 2013, 42, 253-258. [CrossRef]

235. Cohen, F.P.; Valenti, W.C. Opportunities and constraints for developing low-cost aquaculture of seahorses in mangrove estuaries. Aquaculture 2019, 502, 121-127. [CrossRef]

236. Robertson, A.I.; Blaber, S.J.M. Plankton, Epibenthos and Fish Communities. In Tropical Mangrove Ecosystems; Robertson, A.I., Alongi, D.M., Eds.; American Geophysical Union: Washington, DC, USA, 1992; pp. 173-224.

237. Yip, M.; Lim, A.; Chong, V.; Lawson, J.; Foster, S. Food and feeding habits of the seahorses Hippocampus spinosissimus and Hippocampus trimaculatus (Malaysia). J. Mar. Biol. Assoc. U.K. 2014, 95, 1033-1040. [CrossRef]

238. Garcia, L.M.B.; Hilomen-Garcia, G.V.; Celino, F.T.; Gonzales, T.T.; Maliao, R.J. Diet composition and feeding periodicity of the seahorse Hippocampus barbouri reared in illuminated sea cages. Aquaculture 2012, 358-359, 1-5. [CrossRef]

239. Xu, Y.; Mu, J. Study on an integrated eco-aquaculture system for rearing the yellow seahorse, Hippocampus kuda Bleeker. Aquac. Res. 2016, 48, 2868-2875. [CrossRef]

240. Xu, Y.; Lin, J.; Chen, S. Polyculture of the lined seahorse, Hippocampus erectus Perry, 1810 with two species of macroalgae in aquaria. Acta Oceanol. Sin. 2010, 29, 26-32. [CrossRef]

241. Job, S. Integrating marine conservation and sustainable development: Community-based aquaculture of marine aquarium fish. SPC Life Reef Fish Info Bull. 2005, 13, 24-29.

242. Vaidyanathan, T.; Zhang, X.; Balakrishnan, R.; Vincent, A. Catch and trade bans for seahorses can be negated by non-selective fisheries. Aquat. Conserv. Mar. Freshw. Ecosyst. 2021, 31, 43-59. [CrossRef]

243. Gurjão, L.M.; Barros, G.M.L.; Lopes, D.P.; Machado, D.A.N.; Lotufo, T.M.C. Illegal trade of aquarium species through the Brazilian postal service in Ceará State. Mar. Freshw. Res. 2018, 69, 178-185. [CrossRef]

244. De Gurjão, L.M.; Lotufo, T.M.D.C. Native species exploited by marine aquarium trade in Brazil. Biota Neotrop. 2018, 18 , 20170387. [CrossRef]

245. Smith, M.J.; Benítez-Díaz, H.; Clemente-Muñoz, M.Á.; Donaldson, J.; Hutton, J.M.; McGough, H.N.; Medellin, R.A.; Morgan, D.H.; O'Criodain, C.; Oldfield, T.E.; et al. Assessing the impacts of international trade on CITES-listed species: Current practices and opportunities for scientific research. Biol. Conserv. 2011, 144, 82-91. [CrossRef]

246. Meeuwig, J.; Samoilys, M.; Erediano, J.; Koldewey, H. Fishers' Perceptions on the Seahorse Fishery in Central Philippines: Interactive Approaches and an Evaluation of Results. In Fishers' Knowledge in Fisheries Science and Management; Coastal Management Sourcebooks 4; Haggan, N., Neis, B., Baird, I.G., Eds.; UNESCO: Paris, France, 2003; pp. 179-201.

247. Rosa, I.M.; Alves, R.R.; Bonifácio, K.M.; Mourão, J.S.; Osório, F.M.; Oliveira, T.P.; Nottingham, M.C. Fishers' knowledge and seahorse conservation in Brazil. J. Ethnobiol. Ethnomed. 2005, 1, 12. [CrossRef]

248. Ternes, M.L.F.; Gerhardinger, L.C.; Schiavetti, A. Seahorses in focus: Local ecological knowledge of seahorse-watching operators in a tropical estuary. J. Ethnobiol. Ethnomed. 2016, 12, 1-12. [CrossRef]

249. Ulfah, F.; Afrizal; Pratomo, A. Sustainability of seahorses: Lessons learned of local wisdom from Bintan Islands, Riau Islands Province. E3S Web Conf. 2018, 47, 07001. [CrossRef]

250. Perry, A.L.; Vaidyanathan, T.; Giles, B.; Moreau, M.-A.; Picco, C.M.; Vincent, A.C.J. The Catch and Trade of Seahorses in India Pre-Ban; Fisheries Centre Research Reports 28(3); University of British Columbia: Vancouver, BC, Canada, 2020; p. 55. 
251. Hall, H.; Warmolts, D. The Role of Public Aquariums in the Conservation and Sustainability of the Marine Ornamentals Trade. In Marine Ornamental Species: Collection, Culture and Conservation; Cato, J., Brown, B., Eds.; Iowa State Press: Ames, IA, USA, 2003; pp. 307-323.

252. Tlusty, M.F.; Rhyne, A.L.; Kaufman, L.; Hutchins, M.; Reid, G.M.; Andrews, C.; Boyle, P.; Hemdal, J.; McGilvray, F.; Dowd, S. Opportunities for public aquariums to increase the sustainability of the aquatic animal trade. Zoo Biol. 2012, 32, 1-12. [CrossRef] [PubMed]

253. Tlusty, M.F.; Baylina, N.; Rhyne, A.L.; Brown, C.; Smith, M. Public Aquaria. In Marine Ornamental Species Aquaculture; WileyBlackwell: Hoboken, NJ, USA, 2017; pp. 611-622.

254. Anderson, P.A. Acoustic characterization of seahorse tank environments in public aquaria: A citizen science project. Aquac. Eng. 2013, 54, 72-77. [CrossRef]

255. Calado, R. The Role of Public and Private Aquaria in the Culture and Conservation of Marine Ornamentals. In Marine Ornamental Species Aquaculture; Wiley-Blackwell: Hoboken, NJ, USA, 2017; pp. 609-610.

256. Pouil, S.; Tlusty, M.F.; Rhyne, A.L.; Metian, M. Aquaculture of marine ornamental fish: Overview of the production trends and the role of academia in research progress. Rev. Aquac. 2019, 12, 1217-1230. [CrossRef]

257. Leger, J.S.; Violetta, G. Interaction Between Public and Private Aquaria. In Marine Ornamental Species Aquaculture; Wiley-Blackwell: Hoboken, NJ, USA, 2017; pp. 623-634.

258. Pavitt, A.; Malsch, K.; King, E.; Chevalier, A.; Kachelriess, D.; Vannuccini, S.; Friedman, K. CITES and the Sea: Trade in Commercially Exploited CITES-Listed Marine Species; FAO Fisheries and Aquaculture Technical Paper No. 666; FAO: Rome, Italy, $2021 ;$ p. 100. [CrossRef]

259. Hebert, P.D.N.; Cywinska, A.; Ball, S.L.; Dewaard, J.R. Biological identifications through DNA barcodes. Proc. R. Soc. B Biol. Sci. 2003, 270, 313-321. [CrossRef]

260. Staats, M.; Arulandhu, A.J.; Gravendeel, B.; Holst-Jensen, A.; Scholtens, I.; Peelen, T.; Prins, T.W.; Kok, E. Advances in DNA metabarcoding for food and wildlife forensic species identification. Anal. Bioanal. Chem. 2016, 408, 4615-4630. [CrossRef]

261. Van der Walt, K.; Mäkinen, T.; Swartz, E.; Weyl, O. DNA barcoding of South Africa's ornamental freshwater fish-Are the names reliable? Afr. J. Aquat. Sci. 2017, 42, 155-160. [CrossRef]

262. Aubriot, X.; Lowry, P.P.; Cruaud, C.; Couloux, A.; Haevermans, T. DNA barcoding in a biodiversity hot spot: Potential value for the identification of Malagasy Euphorbia L. listed in CITES Appendices I and II. Mol. Ecol. Resour. 2013, 13, 57-65. [CrossRef] [PubMed]

263. Gathier, G.; Van Der Niet, T.; Peelen, T.; Van Vugt, R.R.; Eurlings, M.C.; Gravendeel, B. Forensic identification of CITES protected slimming cactus (Hoodia) using DNA barcoding. J. Forensic Sci. 2013, 58, 1467-1471. [CrossRef]

264. Eurlings, M.C.M.; Lens, F.; Pakusza, C.; Peelen, T.; Wieringa, J.J.; Gravendeel, B. Forensic identification of Indian snakeroot (Rauvolfia serpentina Benth. ex Kurz) using DNA barcoding. J. Forensic Sci. 2013, 58, 822-830. [CrossRef]

265. De Boer, H.J.; Ghorbani, A.; Manzanilla, V.; Raclariu, A.-C.; Kreziou, A.; Ounjai, S.; Osathanunkul, M.; Gravendeel, B. DNA metabarcoding of orchid-derived products reveals widespread illegal orchid trade. Proc. R. Soc. B: Biol. Sci. 2017, 284, 20171182. [CrossRef]

266. Veldman, S.; Kim, S.J.; van Andel, T.R.; Bello Font, M.; Bone, R.E.; Bytebier, B.; Chuba, D.; Gravendeel, B.; Martos, F.; Mpatwa, G.; et al. Trade in Zambian edible orchids-DNA barcoding reveals the use of unexpected orchid taxa for Chikanda. Genes 2018, 9, 595. [CrossRef]

267. Vu, H.-T.; Nguyen, T.-D.; Tran, H.-D.; Vu, Q.-L.; Tran, N.; Nguyen, T.-C.; Luu, P.-N.; Tran, D.-D.; Nguyen, T.-K.; Le, L. Identification of Vietnamese Paphiopedilum species using DNA sequences. Biology 2020, 9, 9. [CrossRef] [PubMed]

268. Peppin, L.; McEwing, R.; Carvalho, G.R.; Ogden, R. A DNA-based approach for the forensic identification of Asiatic black bear (Ursus thibetanus) in a traditional Asian medicine. J. Forensic Sci. 2008, 53, 1358-1362. [CrossRef]

269. Meganathan, P.R.; Dubey, B.; Haque, I. Molecular identification of Indian crocodile species: PCR-RFLP method for forensic authentication. J. Forensic Sci. 2009, 54, 1042-1045. [CrossRef]

270. Dubey, B.; Meganathan, P.R.; Haque, I. Molecular identification of three Indian snake species using simple PCR-RFLP method. J. Forensic Sci. 2010, 55, 1065-1067. [CrossRef] [PubMed]

271. Rehman, A.; Jafar, S.; Raja, N.A.; Mahar, J. Use of DNA barcoding to control the illegal wildlife trade: A CITES case report from Pakistan. J. Bioresour. Manag. 2015, 2, 3. [CrossRef]

272. Mendoza, Á.M.; Torres, M.F.; Paz, A.; Trujillo-Arias, N.; Alvarez, D.L.; Sierra, S.; Forero, F.; Gonzalez, M.A. Cryptic diversity revealed by DNA barcoding in Colombian illegally traded bird species. Mol. Ecol. Resour. 2016, 16, 862-873. [CrossRef] [PubMed]

273. Liu, S.-Y.V.; Chan, C.-L.C.; Lin, O.; Hu, C.-S.; Chen, C.A. DNA barcoding of shark meats identify species composition and CITES-listed species from the markets in Taiwan. PLoS ONE 2013, 8, e79373. [CrossRef]

274. Fields, A.T.; Abercrombie, D.L.; Eng, R.; Feldheim, K.; Chapman, D.D. A novel mini-DNA barcoding assay to identify processed fins from internationally protected shark species. PLoS ONE 2015, 10, e0114844. [CrossRef] [PubMed]

275. Sembiring, A.; Pertiwi, N.P.D.; Mahardini, A.; Wulandari, R.; Kurniasih, E.M.; Kuncoro, A.W.; Cahyani, N.D.; Anggoro, A.W.; Ulfa, M.; Madduppa, H.; et al. DNA barcoding reveals targeted fisheries for endangered sharks in Indonesia. Fish. Res. 2015, 164, 130-134. [CrossRef]

276. Chuang, P.-S.; Hung, T.-C.; Chang, H.-A.; Huang, C.-K.; Shiao, J.-C. The species and origin of shark fins in Taiwan's fishing ports, markets, and customs detention: A DNA barcoding analysis. PLoS ONE 2016, 11, e0147290. [CrossRef] [PubMed] 
277. Steinke, D.; Bernard, A.M.; Horn, R.L.; Hilton, P.; Hanner, R.; Shivji, M.S. DNA analysis of traded shark fins and mobulid gill plates reveals a high proportion of species of conservation concern. Sci. Rep. 2017, 7, 1-6. [CrossRef] [PubMed]

278. Feitosa, L.M.; Martins, A.P.B.; Giarrizzo, T.; Macedo, W.; Monteiro, I.L.; Gemaque, R.; Nunes, J.L.S.; Gomes, F.; Schneider, H.; Sampaio, I.; et al. DNA-based identification reveals illegal trade of threatened shark species in a global elasmobranch conservation hotspot. Sci. Rep. 2018, 8, 1-11. [CrossRef] [PubMed]

279. Wainwright, B.J.; Ip, Y.C.A.; Neo, M.L.; Chang, J.J.M.; Gan, C.Z.; Clark-Shen, N.; Huang, D.; Rao, M. DNA barcoding of traded shark fins, meat and mobulid gill plates in Singapore uncovers numerous threatened species. Conserv. Genet. 2018, 19, 1393-1399. [CrossRef]

280. Johri, S.; Doane, M.P.; Allen, L.; Dinsdale, E.A. Taking advantage of the genomics revolution for monitoring and conservation of chondrichthyan populations. Diversity 2019, 11, 49. [CrossRef]

281. Hoeksema, B.W.; Arrigoni, R. DNA barcoding of a stowaway reef coral in the international aquarium trade results in a new distribution record. Mar. Biodivers. 2020, 50, 1-7. [CrossRef]

282. Steinke, D.; Zemlak, T.S.; Hebert, P.D.N. Barcoding nemo: DNA-based identifications for the ornamental fish trade. PLoS ONE 2009, 4, e6300. [CrossRef]

283. Galbusera, P.H.A.; Gillemot, S.; Jouk, P.; Teske, P.R.; Hellemans, B.; Volckaert, F.A.M.J. Isolation of microsatellite markers for the endangered Knysna seahorse Hippocampus capensis and their use in the detection of a genetic bottleneck. Mol. Ecol. Notes 2007, 7, 638-640. [CrossRef]

284. Luo, W.; Qu, H.; Li, J.; Wang, X.; Lin, Q. A novel method for the identification of seahorses (genus Hippocampus) using cross-species amplifiable microsatellites. Fish. Res. 2015, 172, 318-324. [CrossRef]

285. Wang, B.; Zhang, Y.; Zhang, H.; Lin, Q. Complete mitochondrial genome sequence of the Barbour's seahorse Hippocampus barbouri Jordan \& Richardson, 1908 (Gasterosteiformes: Syngnathidae). Mitochondrial DNA 2014, 26, 851-852. [CrossRef] [PubMed]

286. Nester, G.M.; De Brauwer, M.; Koziol, A.; West, K.M.; DiBattista, J.D.; White, N.E.; Power, M.; Heydenrych, M.J.; Harvey, E.; Bunce, M. Development and evaluation of fish eDNA metabarcoding assays facilitate the detection of cryptic seahorse taxa (family: Syngnathidae). Environ. DNA 2020, 2, 614-626. [CrossRef]

287. Lai, M.; Sun, S.; Chen, J.; Lou, Z.; Qiu, F.; Zhang, G.; Cheng, R. Complete mitochondrial genome sequence for the seahorse adulteration Hippocampus camelopardalis Bianconi 1854. Mitochondrial DNA Part B 2019, 4, 432-433. [CrossRef]

288. Ge, Y.; Zhu, L.; Chen, M.; Zhang, G.; Huang, Z.; Cheng, R. Complete mitochondrial genome sequence for the endangered Knysna seahorse Hippocampus capensis Boulenger 1900. Conserv. Genet. Resour. 2018, 10, 461-465. [CrossRef]

289. Teske, P.R. Mitogenome reconstruction of an endangered African seahorse from a traditional Chinese medicine market was based on a misidentification. BioRxiv Prepr. 2020. [CrossRef]

290. Chang, C.-H.; Lin, H.-Y.; Jang-Liaw, N.-H.; Shao, K.-T.; Lin, Y.-S.; Ho, H.-C. The complete mitochondrial genome of the tiger tail seahorse, Hippocampus comes (Teleostei, Syngnathidae). Mitochondrial DNA 2013, 24, 199-201. [CrossRef] [PubMed]

291. Hanifaturahmah, F.; Perwitasari-Farajallah, D.; Butet, N.A.; Nurilmala, M.; Sudrajat, A.O.; Ochiai, Y. Morphological and molecular identification of seahorses (Hippocampus spp.) from the coast of Sumatra Island, Indonesia. Biodiversitas 2020, 21, 4116-4123. [CrossRef]

292. Lin, Q.; Fan, S.; Zhang, Y.; Xu, M.; Zhang, H.; Yang, Y.; Lee, A.P.; Woltering, J.M.; Ravi, V.; Gunter, H.M.; et al. The seahorse genome and the evolution of its specialized morphology. Nat. Cell Biol. 2016, 540, 395-399. [CrossRef]

293. Lin, Q.; Luo, W.; Wan, S.; Gao, Z. De Novo transcriptome analysis of two seahorse species (Hippocampus erectus and H. mohnikei) and the development of molecular markers for population genetics. PLoS ONE 2016, 11, e0154096. [CrossRef]

294. Lin, Q.; Qiu, Y.; Gu, R.; Xu, M.; Li, J.; Bian, C.; Zhang, H.; Qin, G.; Zhang, Y.; Luo, W.; et al. Draft genome of the lined seahorse, Hippocampus erectus. GigaScience 2017, 6, 1-6. [CrossRef]

295. Silveira, R.B.; Siccha-Ramirez, R.; Silva, J.R.S.; Oliveira, C. Morphological and molecular evidence for the occurrence of three Hippocampus species (Teleostei: Syngnathidae) in Brazil. Zootaxa 2014, 3861, 317-332. [CrossRef] [PubMed]

296. Zhang, Y.; Zhang, H.; Lin, Q.; Huang, L. Complete mitochondrial genome sequence of the lined seahorse Hippocampus erectus Perry, 1810 (Gasterosteiformes: Syngnathidae). Mitochondrial DNA 2013, 26, 659-660. [CrossRef] [PubMed]

297. Zhu, K.-C.; Ma, Q.; Zhang, D.-C. Isolation and characterization of 100 SNP markers in lined seahorse (Hippocampus erectus) using RAD sequencing. Conserv. Genet. Resour. 2020, 12, 589-595. [CrossRef]

298. Correia, M.; Campoy, A.; Madeira, C.; Andrade, J.P. Is filament clipping an effective tool for tissue sampling in Hippocampus guttulatus? Environ. Biol. Fishes 2018, 101, 1517-1523. [CrossRef]

299. Chen, M.; Zhu, L.; Chen, J.; Zhang, G.; Cheng, R.; Ge, Y. The complete mitochondrial genome of the short snouted seahorse Hippocampus hippocampus Linnaeus 1758 (Syngnathiformes: Syngnathidae) and its phylogenetic implications. Conserv. Genet. Resour. 2017, 10, 783-787. [CrossRef]

300. Singh, K.V.; Gopalakrishnan, A.; Lakra, W.S.; Sobti, R.C. Microsatellite loci to determine population structure in the yellow seahorse (Hippocampus kuda) and the three-spotted seahorse (H. trimaculatus). Mar. Biodivers. 2012, 42, 481-488. [CrossRef]

301. Zhang, H.; Zhang, Y.; Lin, Q. Complete mitochondrial genome of the pacific seahorse Hippocampus ingens Girard, 1858 (Gasterosteiformes: Syngnathidae). Mitochondrial DNA 2013, 26, 755-756. [CrossRef]

302. Cheng, R.; Fang, Y.; Ge, Y.; Liu, Q.; Zhang, G. Complete mitochondrial genome sequence of the Jayakar's seahorse Hippocampus jayakari Boulenger, 1900 (Gasterosteiformes: Syngnathidae). Mitochondrial DNA Part B 2017, 2, 593-594. [CrossRef] 
303. Wang, X.; Zhang, Y.; Zhang, H.; Qin, G.; Lin, Q. Complete mitochondrial genomes of eight seahorses and pipefishes (Syngnathiformes: Syngnathidae): Insight into the adaptive radiation of syngnathid fishes. BMC Evol. Biol. 2019, 19, 119. [CrossRef]

304. Hue, N.T.; Tran, N.T.T. A DNA extraction method applied for living seahorses. IFMBE Proc. 2013, 49, 178-183. [CrossRef]

305. Jahari, P.N.S.; Malik, N.F.A.; Shamsir, M.S.; Gilbert, M.T.P.; Salleh, F.M. The first complete mitochondrial genome data of Hippocampus kuda originating from Malaysia. Data Brief 2020, 31, 105721. [CrossRef]

306. Leong, O.B.; Joseph, J.; Kuang, C.C. Genetic Mating System of Spotted Seahorse (Hippocampus kuda). In Proceedings of the 9th UMT In-ternational Symposium on Sustainability Science and Management (UMTAS); Universiti Malaysia Terengganu: Kuala Terengga-nu, Malaysia, 2010; Volume 2, pp. 1-6.

307. Thangaraj, M.; Lipton, A.P. Assessment of genetic variation in closely related seahorse species (Genus: Hippocampus) using mtDNA marker. Indian J. Biotechnol. 2011, 10, 140-142.

308. Yang, Q.-H.; Lu, Z.; Zheng, L.-Y.; Huang, Z.-C.; Lin, Q.; Wu, J.-N.; Zhou, C. The complete mitochondrial genome of the Japanese seahorse, Hipppocampus mohnikei (Syngnathiformes: Syngnathidae) and its phylogenetic implications. Conserv. Genet. Resour. 2017, 9, 613-617. [CrossRef]

309. Li, Y.; Wang, B.; Wang, A.; Yu, X.; Li, Y.; Han, Z.; Fu, J.; Dong, J. Sequence variation of mtDNA control region in Hippocampus japonicus inhabiting Liaoning coast and its applicability as a marker for phylogenetic analysis. J. Fish. China 2017, 41, 1073-1082. (In Chinese) [CrossRef]

310. González, R.; Dinghi, P.; Corio, C.; Medina, A.; Maggioni, M.; Storero, L.; Gosztonyi, A. Reply to Luzzatto et al. Genetic evidence and new morphometric data as essential tools to identify the Patagonian seahorse Hippocampus patagonicus (Pisces, Syngnathidae) by González et al. J. Fish Biol. 2014, 85, 1300-1302. [CrossRef]

311. Luzzatto, D.C.; Sieira, R.; Pujol, M.G.; de Astarloa, J.M.D. The presence of the seahorse Hippocampus patagonicus in the Ar-gentine Sea based on the Cytochrome b sequence of mitochondrial DNA. Cybium 2012, 36, 329-333.

312. Luzzatto, D.C.; Estalles, M.L.; De Astarloa, J.M.D. Comment on 'Genetic evidence and new morphometric data as essential tools to identify the Patagonian seahorse Hippocampus patagonicus (Pisces, Syngnathidae) by González et al. (2014)'. J. Fish Biol. 2014, 85, 1297-1299. [CrossRef] [PubMed]

313. Wang, X.; Zhang, Y.; Zhang, H.; Meng, T.; Lin, Q. Complete mitochondrial genome sequence of the longsnout seahorse Hippocampus reidi (Ginsburg, 1933; Gasterosteiformes: Syngnathidae). Mitochondrial DNA 2014, 27, 1401-1402. [CrossRef]

314. Wang, X.; Han, X.; Zhang, Y.; Liu, S.; Lin, Q. Phylogenetic analysis and genetic structure of the seahorse, Hippocampus fuscus from the Arabian and Red Sea based on mitochondrial DNA sequences. Mitochondrial DNA Part A 2018, 30, 165-171. [CrossRef]

315. Liu, S.; Zhang, Y.; Wang, C.; Lin, Q. Complete mitochondrial genome sequence of the hedgehog seahorse Hippocampus spinosissimus Weber, 1933 (Gasterosteiformes: Syngnathidae). Mitochondrial DNA Part A 2015, 27, 2767-2768. [CrossRef]

316. Teske, P.R.; Lourie, S.A.; Matthee, C.A.; Green, D.M. Hippocampus queenslandicus Horne, 2001-A new seahorse species or yet another synonym? Aust. J. Zool. 2007, 55, 139-145. [CrossRef]

317. Wang, Z.; Ge, Y.; Cheng, R.; Huang, Z.; Chen, Z.; Zhang, G. Sequencing and analysis of the complete mitochondrial genome of Hippocampus spinosissimus Weber, 1913 (Gasterosteiformes: Syngnathidae). Mitochondrial DNA Part A 2015, 28, 303-304. [CrossRef]

318. Chang, C.-H.; Shao, K.-T.; Lin, Y.-S.; Liao, Y.-C. The complete mitochondrial genome of the three-spot seahorse, Hippocampus trimaculatus (Teleostei, Syngnathidae). Mitochondrial DNA 2013, 24, 665-667. [CrossRef] [PubMed]

319. Short, G.; Harasti, D.; Hamilton, H. Hippocampus whitei Bleeker, 1855, a senior synonym of the southern Queensland seahorse $H$. procerus Kuiter, 2001: Molecular and morphological evidence (Teleostei, Syngnathidae). ZooKeys 2019, 824, 109-133. [CrossRef] [PubMed]

320. Chang, C.-H.; Jang-Liaw, N.-H.; Lin, Y.-S.; Fang, Y.-C.; Shao, K.-T. Authenticating the use of dried seahorses in the traditional Chinese medicine market in Taiwan using molecular forensics. J. Food Drug Anal. 2013, 21, 310-316. [CrossRef]

321. Hou, F.; Cao, J.; Wang, X.; Wang, S.; Peng, C.; Guo, J. Specific authentication of Hippocampus based on SNP markers. Biochem. Syst. Ecol. 2017, 71, 131-136. [CrossRef]

322. Hou, F.; Wen, L.; Peng, C.; Guo, J. Identification of marine traditional Chinese medicine dried seahorses in the traditional Chinese medicine market using DNA barcoding. Mitochondrial DNA Part A 2018, 29, 107-112. [CrossRef] [PubMed]

323. Sanders, J.G.; Cribbs, J.E.; Fienberg, H.G.; Hulburd, G.C.; Katz, L.S.; Palumbi, S.R. The tip of the tail: Molecular identification of seahorses for sale in apothecary shops and curio stores in California. Conserv. Genet. 2007, 9, 65-71. [CrossRef]

324. Wang, X.; Zhong, H.; Guo, J.; Hou, F. Morphology and molecular identification of the zoological origin of medicinal seahorses in Chinese herbal markets. Mitochondrial DNA Part A 2020, 31, 1-11. [CrossRef]

325. Serite, C.R.; Ntshudisane, O.K.; Swart, E.; Simbine, L.; Jaime, G.L.M.; Teske, P.R. Limitations of DNA barcoding in deter-mining the origin of smuggled seahorses and pipefishes. BioRxiv Prepr. 2020. [CrossRef]

326. López, A.; Vera, M.; Otero-Ferrer, F.; Pardo, B.G.; Martínez, P.; Molina, L.; Bouza, C. Species identification and genetic structure of threatened seahorses in Gran Canaria Island (Spain) using mitochondrial and microsatellite markers. Conserv. Genet. 2010, 11, 2431-2436. [CrossRef]

327. López, A.; Vera, M.; Planas, M.; Bouza, C. Conservation genetics of threatened Hippocampus guttulatus in vulnerable habitats in NW spain: Temporal and spatial stability of wild populations with flexible polygamous mating system in captivity. PLoS ONE 2015, 10, e0117538. [CrossRef] [PubMed] 
328. Riquet, F.; Lieutard-Haag, C.; Serluca, G.; Woodall, L.; Claude, J.; Louisy, P.; Bierne, N. Effective population size and heterozygosityfitness correlations in a population of the Mediterranean lagoon ecotype of long-snouted seahorse Hippocampus guttulatus. Conserv. Genet. 2019, 20, 1281-1288. [CrossRef]

329. Van De Vliet, M.S.; Diekmann, O.E.; Serrão, E.T.A. Highly polymorphic microsatellite markers for the short-snouted seahorse (Hippocampus hippocampus), including markers from a closely related species the long-snouted seahorse (Hippocampus guttulatus) Conserv. Genet. Resour. 2009, 1, 93-96. [CrossRef]

330. Zhang, N.; Xu, B.; Mou, C.; Yang, W.; Wei, J.; Lu, L.; Zhu, J.; Du, J.; Wu, X.; Ye, L.; et al. Molecular profile of the unique species of traditional Chinese medicine, Chinese seahorse (Hippocampus kuda Bleeker). FEBS Lett. 2003, 550, 124-134. [CrossRef]

331. Hamilton, H.; Saarman, N.; Short, G.; Sellas, A.B.; Moore, B.; Hoang, T.; Grace, C.L.; Gomon, M.; Crow, K.; Simison, W.B. Molecular phylogeny and patterns of diversification in syngnathid fishes. Mol. Phylogenet. Evol. 2017, 107, 388-403. [CrossRef]

332. Koh, B.S.; Song, C.B. Molecular phylogeny of Syngnathiformes fishes inferred from mitochondrial cytochrome b DNA se-quences. J. Kor. Fish. Soc. 2004, 37, 405-413.

333. Nurilmala, M.; Nurhayati, K.H.; Butet, N.A.; Sudrajat, A.O. Molecular marker based on 16S rRNA gene for seahorse (Hippocampus spp.) from Bintan Island-Indonesia. IOP Conf. Ser. Earth Environ. Sci. 2019, 278, 012054. [CrossRef]

334. Nurilmala, M.; Sari, E.M.; Abdullah, A.; Hizbullah, H.H.; Butet, N.A.; Sudrajat, A.O. DNA barcoding for seahorse identification and its potential as antioxidant and stimulant indicator. IOP Conf. Ser. Earth Environ. Sci. 2019, 404, 012002. [CrossRef]

335. Teske, P.R.; Cherry, M.I.; Matthee, C.A. The evolutionary history of seahorses (Syngnathidae: Hippocampus): Molecular data suggest a West Pacific origin and two invasions of the Atlantic Ocean. Mol. Phylogenet. Evol. 2004, 30, 273-286. [CrossRef]

336. Wilson, A.B.; Ahnesjo, I.; Vincent, A.C.J.; Meyer, A. The dynamics of male brooding, mating patterns, and sex roles in pipefishes and seahorses (family Syngnathidae). Evolution 2003, 57, 1374-1386. [CrossRef]

337. Wilson, A.B.; Orr, J.W. The evolutionary origins of Syngnathidae: Pipefishes and seahorses. J. Fish Biol. 2011, 78, 1603-1623. [CrossRef]

338. Casey, S.P.; Hall, H.J.; Stanley, H.F.; Vincent, A.C. The origin and evolution of seahorses (genus Hippocampus): A phylogenetic study using the cytochrome b gene of mitochondrial DNA. Mol. Phylogenet. Evol. 2004, 30, 261-272. [CrossRef]

339. Teske, P.R.; Hamilton, H.; Matthee, C.A.; Barker, N.P. Signatures of seaway closures and founder dispersal in the phylogeny of a circumglobally distributed seahorse lineage. BMC Evol. Biol. 2007, 7, 138. [CrossRef] [PubMed]

340. Woodall, L.C.; Koldewey, H.J.; Santos, S.V.; Shaw, P.W. First occurrence of the lined seahorse Hippocampus erectus in the eastern Atlantic Ocean. J. Fish Biol. 2009, 75, 1505-1512. [CrossRef] [PubMed]

341. Lourie, S.A. Spatial genetic patterns in the Hippocampus barbouri species group (Teleostei: Syngnathidae) across the Coral Triangle. In Proceedings of the 10th International Coral Reef Symposium, Okinawa, Japan, 28 June-2 July 2003; pp. 478-484.

342. Lourie, S.A.; Green, D.M.; Vincent, A.C.J. Dispersal, habitat differences, and comparative phylogeography of Southeast Asian seahorses (Syngnathidae: Hippocampus). Mol. Ecol. 2005, 14, 1073-1094. [CrossRef]

343. Cheng, R.; Liao, G.; Ge, Y.; Yang, B.; Zhang, G. Complete mitochondrial genome of the great seahorse Hippocampus kelloggi Jordan \& Snyder, 1901 (Gasterosteiformes: Syngnathidae). Mitochondrial DNA Part A 2015, 28, 227-228. [CrossRef]

344. Zhang, Y.-H.; Qin, G.; Zhang, H.-X.; Wang, X.; Lin, Q. DNA barcoding reflects the diversity and variety of brooding traits of fish species in the family Syngnathidae along China's coast. Fish. Res. 2017, 185, 137-144. [CrossRef]

345. Teske, P.R.; Hamilton, H.; Palsbøll, P.J.; Choo, C.K.; Gabr, H.; Lourie, S.A.; Santos, M.; Sreepada, A.; Cherry, M.I.; Matthee, C.A. Molecular evidence for long-distance colonization in an Indo-Pacific seahorse lineage. Mar. Ecol. Prog. Ser. 2005, 286, 249-260. [CrossRef]

346. Song, H.Y.; Mabuchi, K.; Satoh, T.P.; Moore, J.A.; Yamanoue, Y.; Miya, M.; Nishida, M. Mitogenomic circumscription of a novel percomorph fish clade mainly comprising "Syngnathoidei" (Teleostei). Gene 2014, 542, 146-155. [CrossRef] [PubMed]

347. Ashe, J.L.; Wilson, A.B. Navigating the southern seas with small fins: Genetic connectivity of seahorses (Hippocampus abdominalis) across the Tasman Sea. J. Biogeogr. 2019, 47, 207-219. [CrossRef]

348. Nickel, J.; Cursons, R. Genetic diversity and population structure of the pot-belly seahorse Hippocampus abdominalis in New Zealand. N. Z. J. Mar. Freshw. Res. 2012, 46, 207-218. [CrossRef]

349. Mkare, T.K.; van Vuuren, B.J.; Teske, P.R. Conservation implications of significant population differentiation in an endangered estuarine seahorse. Biodivers. Conserv. 2017, 26, 1275-1293. [CrossRef]

350. Teske, P.R.; Cherry, M.I.; Matthee, C. Population genetics of the endangered Knysna seahorse, Hippocampus capensis. Mol. Ecol. 2003, 12, 1703-1715. [CrossRef]

351. Boehm, J.T.; Waldman, J.; Robinson, J.D.; Hickerson, M.J. Population genomics reveals seahorses (Hippocampus erectus) of the western mid-Atlantic coast to be residents rather than vagrants. PLoS ONE 2015, 10, e0116219. [CrossRef]

352. Rose, E.; Masonjones, H.D.; Jones, A.G. A DNA-based assessment of the phylogenetic position of a morphologically distinct, anchialine-lake-restricted seahorse. J. Hered. 2016, 107, 553-558. [CrossRef]

353. Riquet, F.; Liautard-Haag, C.; Woodall, L.; Bouza, C.; Louisy, P.; Hamer, B.; Otero-Ferrer, F.; Aublanc, P.; Béduneau, V.; Briard, O.; et al. Parallel pattern of differentiation at a genomic island shared between clinal and mosaic hybrid zones in a complex of cryptic seahorse lineages. Evolution 2019, 73, 817-835. [CrossRef]

354. Saarman, N.P.; Louie, K.D.; Hamilton, H. Genetic differentiation across eastern Pacific oceanographic barriers in the threatened seahorse Hippocampus ingens. Conserv. Genet. 2010, 11, 1989-2000. [CrossRef] 
355. Choudhary, B.K.; Lakra, W.S.; Choudhary, M. Mitochondrial DNA phylogeny of Indian seahorse (Hippocampus kuda) based on cytochrome B gene sequences. Bioscan 2014, 9, 931-936.

356. Goswami, M.; Thangaraj, K.; Chaudhary, B.K.; Bhaskar, L.V.S.K.; Gopalakrishnan, A.; Joshi, M.B.; Singh, L.; Lakra, W.S. Genetic heterogeneity in the Indian stocks of seahorse (Hippocampus kuda and Hippocampus trimaculatus) inferred from mtDNA cytochrome b gene. Hydrobiologia 2009, 621, 213-221. [CrossRef]

357. Panithanarak, T.; Karuwancharoen, R.; Na-Nakorn, U.; Nguyen, T.T.T. Population genetics of the spotted seahorse (Hippocampus $k u d a)$ in Thai waters: Implications for conservation. Zool. Stud. 2010, 49, 564-576.

358. Panithanarak, T. Phylogeography of three commercially important seahorses (genus Hippocampus) in Thai waters: An implication from collective sequence data. J. Fish. Environ. 2020, 44, 1-15.

359. Panithanarak, T.; Karuwanjaroen, R. A preliminary study of genetic differentiation in the Japanese seahorse (Hippocampus mohnikei) populations: A possibility of cryptic species. Burapha Sci. J. 2019, 24, 124-137. (In Thai)

360. Zhang, Y.; Pham, N.K.; Zhang, H.; Lin, J.; Lin, Q. Genetic variations in two seahorse species (Hippocampus mohnikei and Hippocampus trimaculatus): Evidence for middle Pleistocene population expansion. PLoS ONE 2014, 9, e105494. [CrossRef]

361. Mobley, K.B.; Small, C.M.; Jones, A.G. The genetics and genomics of Syngnathidae: Pipefishes, seahorses and seadragons. J. Fish Biol. 2011, 78, 1624-1646. [CrossRef]

362. Whittington, C.M.; Griffith, O.W.; Qi, W.; Thompson, M.B.; Wilson, A.B. Seahorse brood pouch transcriptome reveals common genes associated with vertebrate pregnancy. Mol. Biol. Evol. 2015, 32, 3114-3131. [CrossRef]

363. Jones, A.G.; Kvarnemo, C.; Moore, G.I.; Simmons, L.W.; Avise, J.C. Microsatellite evidence for monogamy and sex-biased recombination in the Western Australian seahorse Hippocampus angustus. Mol. Ecol. 1998, 7, 1497-1505. [CrossRef]

364. Mukai, T.; Tsuihiji, T.; Sato, T.; Morisawa, M. Mitochondrial DNA divergence in the seahorse, Hippocampus coronatus (Syngnathiformes: Syngnathidae), collected from Sagami Bay. Jap. J. Ichthyol. 2000, 47, 139-143. (In Japanese)

365. Ho, N.K.P.; Ho, A.; Underwood, G.D.; Underwood, A.; Zhang, D.; Lin, J. A simple molecular protocol for the identification of hybrid Western Atlantic seahorses, Hippocampus erectus $\times$ H. reidi, and potential consequences of hybrids for conservation. J. Zoo Aquar. Res. 2015, 3, 11-20. [CrossRef]

366. Luo, W.; Wang, X.; Qu, H.; Qin, G.; Zhang, H.; Lin, Q. Genomic structure and expression pattern of MHC II $\alpha$ and II $\beta$ genes reveal an unusual immune trait in lined seahorse Hippocampus erectus. Fish Shellfish. Immunol. 2016, 58, 521-529. [CrossRef] [PubMed]

367. Qin, G.; Luo, W.; Tan, S.; Zhang, B.; Ma, S.; Lin, Q. Dimorphism of sex and gonad-development-related genes in male and female lined seahorse, Hippocampus erectus, based on transcriptome analyses. Genomics 2019, 111, 260-266. [CrossRef]

368. Qu, H.; Luo, W.; Lin, Q. Development of SNP markers in lined seahorse (Hippocampus erectus) based on transcriptome sequencing. Conserv. Genet. Resour. 2015, 8, 1-4. [CrossRef]

369. Zhang, H.; Qin, G.; Sun, J.; Zhang, B.; Lin, Q. The evolution and functional characterization of lined seahorse (Hippocampus erectus) CCKs involved in fasting and thermal stress response. Gen. Comp. Endocrinol. 2018, 255, 56-63. [CrossRef]

370. Lazic, T.; Pierri, C.; Cardone, F.; Cariani, A.; Colangelo, P.; Corriero, G.; Ferrari, A.; Marzano, M.; Messinetti, S.; Pesole, G.; et al Genetic structure of the long-snouted seahorse, Hippocampus guttulatus, in the Central-Western Mediterranean Sea. Biol. J. Linn. Soc. 2020, 130, 771-782. [CrossRef]

371. Woodall, L.C.; Koldewey, H.J.; Shaw, P.W. Serial monogamy in the European long-snouted seahorse Hippocampus guttulatus. Conserv. Genet. 2011, 12, 1645-1649. [CrossRef]

372. Woodall, L.C.; Koldewey, H.J.; Boehm, J.T.; Shaw, P.W. Past and present drivers of population structure in a small coastal fish, the European long snouted seahorse Hippocampus guttulatus. Conserv. Genet. 2015, 16, 1139-1153. [CrossRef]

373. Woodall, L.C.; Otero-Ferrer, F.; Correia, M.; Curtis, J.M.R.; Garrick-Maidment, N.; Shaw, P.W.; Koldewey, H.J. A synthesis of European seahorse taxonomy, population structure, and habitat use as a basis for assessment, monitoring and conservation. Mar. Biol. 2018, 165, 1-19. [CrossRef]

374. Woodall, L.C.; Koldewey, H.J.; Shaw, P.W. Historical and contemporary population genetic connectivity of the European shortsnouted seahorse Hippocampus hippocampus and implications for management. J. Fish Biol. 2011, 78, 1738-1756. [CrossRef] [PubMed]

375. Han, S.-Y.; Rho, S.; Noh, G.E.; Kim, J.-K. Interspecific hybridization in seahorses: Artificially produced hybrid offspring of Hippocampus kuda and Hippocampus reidi. Fish. Aquat. Sci. 2018, 21, 11. [CrossRef]

376. Rose, E.; Small, C.M.; Saucedo, H.A.; Harper, C.; Jones, A.G. Genetic evidence for monogamy in the dwarf seahorse, Hippocampus zosterae. J. Hered. 2014, 105, 828-833. [CrossRef] [PubMed]

377. Montes, M.A.; Cardoso, M.L.V.; Neves, C.H.C.B.; Garcia, A.C.L.; Da Silva, J.C.; Silveira, R.B. Genetic diversity and populational structure of the seahorse Hippocampus reidi (Syngnathidae) in north-eastern Brazil: A conservationist approach. Aquat. Conserv. Mar. Freshw. Ecosyst. 2018, 28, 1114-1122. [CrossRef]

378. Song, H.; Mabuchi, K. Complete mitochondrial genome sequence of the thorny seahorse Hippocampus histrix (Gasterosteiformes: Syngnathidae). Mitochondrial DNA 2013, 25, 7-8. [CrossRef]

379. Kawahara, R.; Miya, M.; Mabuchi, K.; Lavoué, S.; Inoue, J.G.; Satoh, T.P.; Kawaguchi, A.; Nishida, M.; Kawahara-Miki, R. Interrelationships of the 11 gasterosteiform families (sticklebacks, pipefishes, and their relatives): A new perspective based on whole mitogenome sequences from 75 higher teleosts. Mol. Phylogenet. Evol. 2008, 46, 224-236. [CrossRef]

380. Zhang, Z.; Chen, Z.; Zhao, L.; Song, N.; Gao, T. Complete mitochondrial DNA genome of Hippocampus mohnikei (Gasterosteiformes: Syngnathidae). Mitochondrial DNA Part A 2015, 28, 127-128. [CrossRef] [PubMed] 
381. Panithanarak, T. Phylogeny of Thai seahorses inferred from mitochondrial DNA cytochrome $b$ gene. In Proceedings of the Burapha University International Conference, Bangsaen, Chonburi, Thailand, 10-12 July 2015; pp. 1010-1023.

382. Liu, Y.; Wu, Y.; Qin, G.; Chen, Y.; Wang, X.; Lin, Q. Bioaccumulation and reproductive toxicity of bisphenol A in male-pregnant seahorse (Hippocampus erectus) at environmentally relevant concentrations. Sci. Total Environ. 2021, 753, 141805. [CrossRef] [PubMed]

383. Kleiber, D.; Blight, L.K.; Caldwell, I.R.; Vincent, A.C.J. The importance of seahorses and pipefishes in the diet of marine animals. Rev. Fish Biol. Fish. 2011, 21, 205-223. [CrossRef]

384. Mastrangelli, A.; Silveira, R.B.; Burato, M.; Baldassin, P.; Werneck, M.R. First report of Lepidochelys olivacea feeding on Hippocampus patagonicus in Brazil. Mar. Turtle Newsl. 2019, 159, 26-27.

385. Silveira, R.B. Presence of the seahorse Hippocampus reidi (Pisces: Syngnathidae) in diet of marine fish in northeastern Brazil. Oceanogr. Fish. Open Access J. 2020, 12, 1-3. [CrossRef]

386. Huang, D. Threatened reef corals of the world. PLoS ONE 2012, 7, e34459. [CrossRef]

387. Curnick, D.J.; Head, C.E.I.; Huang, D.; Crabbe, M.J.C.; Gollock, M.; Hoeksema, B.W.; Johnson, K.G.; Jones, R.; Koldewey, H.J.; Obura, D.O.; et al. Setting evolutionary-based conservation priorities for a phylogenetically data-poor taxonomic group (Scleractinia). Anim. Conserv. 2015, 18, 303-312. [CrossRef]

388. Isaac, N.J.B.; Pearse, W.D. The Use of EDGE (Evolutionary Distinct Globally Endangered) and EDGE-Like Metrics to Evaluate Taxa for Conservation. In Phylogenet. Diversity; Scherson, R., Faith, D., Eds.; Springer: Cham, Switzerland, 2018 ; pp. $27-39$.

389. Foster, S.; Vincent, A. Holding governments accountable for their commitments: CITES Review of Significant Trade for a very high-volume taxon. Glob. Ecol. Conserv. 2021, 27, e01572. [CrossRef]

390. Pettier, J.-P. Re-enchanting the world: Seahorses' magic and the global trade of affect for wildlife. Environ. Hist. 2019, $24,711-717$. [CrossRef] 